\title{
Paradigm Shifts on Merger Efficiencies in Antitrust Analysis
}

\author{
Jéssica Dutra*
}

INTRODUCTION

Efficiencies are often used as a motivation for mergers. There is a trade-off between the improvement of society's welfare generated by mergers when the resulting firm achieves significant efficiencies, and the potential consumer harm generated by the increase in market power. ${ }^{1}$ The question then becomes not purely whether mergers are capable of producing efficiencies, but to which extent antitrust/competition policy will take them under consideration, ${ }^{2}$ either placing emphasis on consumer protection or total welfare. ${ }^{3}$

Established in conjunction between the U.S. Department of Justice and the Federal Trade Commission (the Agencies), the 2010 Horizontal Merger Guidelines (2010 Guidelines) state that "[t]he Agencies seek to identify and challenge competitively harmful mergers while avoiding unnecessary interference with mergers that are either competitively beneficial or neutral."4 Mergers in the United States are formally evaluated under the Rule of Reason - a legal doctrine that establishes that antitrust cases must be evaluated on the merits, based on evidence of each particular case, to establish whether the conduct at issue yields an

\footnotetext{
* Jéssica Dutra, Ph.D., is a Senior Economist at Economists Incorporated in Washington, DC, where she consults on competition matters on a wide range of industries including health and the electric power industries. She may be contacted at dutra.j@ei.com.

1. See Oliver E. Williamson, Economies as an Antitrust Defense: The Welfare Tradeoffs, 58 Am. ECON. Rev. 18 (1968) [hereinafter Williamson, The Welfare Tradeoffs]; Oliver E. Williamson, Economies as an Antitrust Defense Revisited, 125 U. PA. L. REV. 699, 705 (1977).

2. Ilene Knable Gotts \& Calvin S. Goldman, The Role of Efficiencies in M\&A Global Antitrust Review: Still in Flux?, in FORDHAM CORPORATE LAW INSTITUTE: INTERNATIONAL ANTITRUST LAW \& POLICY 201 (Barry E. Hawk ed., 2003).

3. See Daniel J. Gifford \& Robert T. Kudrle, The Atlantic Divide in Antitrust: An EXAMINATION OF US AND EU COMPETITION POLICY 25 (2015) (exploring the "meanings that may attach to 'welfare' as the primary goal of competition policy and how economic welfare ... relate[s] to ... monopolization in the United States and dominance in Europe").

4. U.S. Dep'T of Justice \& Fed. Trade COMm'N, Horizontal Merger Guidelines 1 (2010), https://www.justice.gov/sites/default/files/atr/legacy/2010/08/19/hmg-2010.pdf [https:// perma.cc/KM9N-2Z4U] [hereinafter 2010 HORIZONTAL MERGER GUIDELINES].
} 
unreasonable restraint of trade, and is thus illegal. ${ }^{5}$ Some other anticompetitive practices are considered per se illegal-such as price fixing - and thus do not require further in-depth analysis. ${ }^{6}$ Since the likelihood of anticompetitive harm from mergers can be influenced by whether the merger generates efficiencies, it seems natural that those efficiencies should be taken under consideration in a Rule of Reason analysis.

The 2010 Guidelines acknowledged that "a primary benefit of mergers to the economy is their potential to generate significant efficiencies and thus enhance the merged firm's ability and incentive to compete, which may result in lower prices, improved quality, enhanced service, or new products." $" 7$ Especially as it relates to estimates of price increase, the 2010 Guidelines also noted that "[i]n a unilateral effects context, incremental cost reductions may reduce or reverse any increases in the merged firm's incentive to elevate price" and thus, at least in principle, should be incorporated into any notion of post-merger price approximations relating to unilateral effects. ${ }^{8}$ Nevertheless, the 2010 Guidelines found that efficiency claims alone will not be enough to justify a merger, since "[e]ven when efficiencies generated through a merger enhance a firm's ability to compete, however, a merger may have other effects that may lessen competition and make the merger anticompetitive." "9

However, in their antitrust analysis trajectory, the Agencies have been nothing short of skeptical when incorporating efficiency claims of procompetitive effects in Rule of Reason analysis. ${ }^{10}$ In order to be taken into consideration into merger analysis, efficiency claims by the merging parties have to be merger-specific and verifiable, which have historically been interpreted to exclude most efficiency claims related to economies of scale, since scale can at least hypothetically be obtained other than through

5. Herbert J. Hovenkamp, The Rule of Reason, 70 FLA. L. REV. 81, 83 (2018).

6. Id.

7. 2010 Horizontal MERGER GUIDELINES, supra note $4, \S 10$.

8. Id.

9. Id.

10. For a comprehensive review of the historical evolution of antitrust policy regarding merger efficiency claims on both the United States and European Union, see GIFFORD \& KUDRLE, supra note 3, at 39; Konstanze Kinne, Efficiencies in Merger Analysis, INTERECONOMICS, Nov.-Dec. 1999, at 297, 297-302 (1999) (explaining in a little more detail specificities on the German case); Daniel A. Crane, Rethinking Merger Efficiencies, 110 MicH. L. REV. 347 (2011) (going through the asymmetries and implicit bias of competition agencies both in the U.S. and European Union when it comes to the burden of proof and magnitude arising from potential mergers as opposed to figures regarding harm to competition). 
mergers. ${ }^{11}$ The 2010 Guidelines stated:

The Agencies credit only those efficiencies likely to be accomplished with the proposed merger and unlikely to be accomplished in the absence of either the proposed merger or another means having comparable anticompetitive effects. These are termed merger-specific efficiencies....

Efficiency claims will not be considered if they are vague, speculative, or otherwise cannot be verified by reasonable means. ...

Cognizable efficiencies are merger-specific efficiencies that have been verified and do not arise from anticompetitive reductions in output or service. Cognizable efficiencies are assessed net of costs produced by the merger or incurred in achieving those efficiencies. ${ }^{12}$

With the adoption of the Hart-Scott-Rodino Antitrust Improvements Act of $1976,{ }^{13}$ merger analysis became prophylactic, and inferences of potential anticompetitive harm arising from a merger must be done ex ante. It becomes clear how the difficulty in producing proof of efficiency claims is a major hindrance to its adoption in merger analysis. ${ }^{14}$

This paper is organized as follows: Part I explores the relevance of which welfare standard is used in antitrust in how efficiencies will be taken under consideration in merger analyses. Part II uses text mining to make a historical analysis of U.S. antitrust policy. Part III explores the implications of using market concentration as a proxy for market power in the presence of efficiencies by designing a Monte Carlo study. Part IV offers the results and analysis of the accuracy of the Herfindahl Hirschman Index as a merger screening tool in the presence of efficiencies.

\section{EFFICIENCIES AND THE CONSUMER WELFARE STANDARD}

Oliver Williamson has shown the trade-off between the improvement of society's welfare generated by mergers when the resulting firm achieves significant efficiencies, as well as the potential consumer harm generated by the increase in market power. ${ }^{15}$ The baseline of Williamson's model is a simple market, in which existent market structure is relatively competitive and two firms in this market have the opportunity to combine

11. Joseph Farrell \& Carl Shapiro, Scale Economies and Synergies in Horizontal Merger Analysis, 68 ANTITRUST L.J. 685, 689-90 (2001).

12. 2010 HorizontAl MERGER GUIDELINES, supra note 4, $\S 10$.

13. 15 U.S.C. § $18 \mathrm{a}(2018)$.

14. Joseph Kattan, Efficiencies and Merger Analysis, 62 ANTITRUST L.J. 513, 535 (1994).

15. See Williamson, The Welfare Tradeoffs, supra note 1, at 18-36. 
and become more efficient. ${ }^{16}$ The dynamics then portray two simultaneous effects: (1) the gained efficiency diminishes cost, which is total welfare increasing, part of which will be passed through to consumers; and (2) the concentration is translated into gains in the ability to price above the competitive level (i.e., market power). ${ }^{17}$ The ultimate and net effect for society will depend on the magnitude of cost savings, as well as the deadweight loss caused by gains in market power. ${ }^{18}$ The net effect for consumers depend additionally on the pass-through of these cost savings onto consumers. ${ }^{19}$

The consequences of the model can be analyzed in many different ways. Mergers, in the presence of efficiencies, may be welfare ${ }^{20}$ increasing. The presence of efficiencies is not a sufficient condition for a net positive effect, but it signals that there is this possibility, and at the very least those should be taken under consideration. It is also possible that a merger in the presence of efficiencies may be welfare increasing for society while harming consumers. This is the main source of discussion of adopting a total welfare vs. a consumer welfare standard. In other words, should antitrust be concerned solely with the potential harm to consumers, or should society's welfare be the primary goal?

Most economies follow the consumer defense approach as opposed to the total welfare approach. From the major countries, Canada, ${ }^{21}$ Australia, ${ }^{22}$ and New Zealand openly follow the total welfare description. ${ }^{23}$ If emphasis is on consumer welfare, the question is not whether the merger generates enough efficiencies to offset deadweight loss, but whether the efficiencies are significant enough to offset firm's incentive to raise

6. Id. at 21 .

17. Id. at $21-24$.

18. Id. at 22 .

19. Id.

20. I purposefully did not specify whose welfare, because it could in fact increase both public and society's or just one of them, but I will break this down in more detail later on.

21. Marc Duhamel, On the Social Welfare Objectives of Canada's Antitrust Statute, 29 CANADIAN PUB. POL'Y 301, 302 (2003).

22. Organisation for Economic Co-operation and Development, OECD Reviews of Regulatory Reform: Competition Policy in Australia, at 13 (2010), http://www.oecd.org/regreform/regulatory -policy/44529918.pdf [https://perma.cc/79BB-DLGA] (“A recent statement... by the Australian Competition Tribunal favours [the total welfare approach] but with the caveat that benefits to producers should weigh less than benefits to end-consumers.").

23. Kenneth Heyer, Consumer Welfare and the Legacy of Robert Bork, 57 J.L. \& ECON. S19, S26 n.5 (2014). 
prices, ${ }^{24}$ a much harder threshold to reach. ${ }^{25}$

Additional considerations regarding the objectives of welfare standards can be seen in José Azar et al., which stated that, "[w]hile consumers are the main focus of antitrust enforcement, the weakening of antitrust enforcement has likely also adversely impacted workers, thus contributing to increasing inequality." 26 Antitrust analyses are shaped by welfare standards and, more specifically, by questions involving whose welfare should be considered. ${ }^{27}$

According to Kenneth Heyer, competition should not be the goal of antitrust, but rather the means to efficiency, which ought to be the primary goal. ${ }^{28}$ Part II describes the journey of efficiencies as an antitrust defense over time in the United States.

\section{EFFICIENCIES IN U.S. MERGER GUIDELINES AND HISTORIC BACKGROUND}

There are many historic analyses and perspectives of antitrust in existing literature. This paper provides a quantitative approach to the evolution of antitrust analysis based on text mining techniques in antitrust cases in which the Agencies have taken public enforcement actions. ${ }^{29}$ Text

24. Howard Shelanski, Efficiency Claims and Antitrust Enforcement, in 1 OXFORD HANDBOOK OF INTERNATIONAL ANTITRUST ECONOMICS (Roger D. Blair \& Daniel Sokol eds., 2014).

25. Gregory J. Werden, A Robust Test for Consumer Welfare Enhancing Mergers Among Sellers of Differentiated Products, 44 J. INDUS. ECON. 409, 412-13 (1996).

26. José Azar et al., Antitrust and Labor Market Power, ECON. FOR INCLUSIVE ProsPERITY, May 2019 , at 1,1 .

27. Kenneth Heyer, Welfare Standards and Merger Analysis: Why Not the Best?, 2 COMPETITION POL'Y INT'L 2-3 (2006); see also Joseph F. Brodley, The Economic Goals of Antitrust: Efficiency, Consumer Welfare, and Technological Progress, 62 N.Y.U. L. REV. 1020, 1041-42 (1987) (arguing consumer welfare must be considered in conjunction with economic efficiency for the purpose of antitrust analysis).

28. William J. Kolaksy \& Andrew R. Dick, The Merger Guidelines and the Integration of Efficiencies Into Antitrust Review of Horizonal Mergers, 71 ANTITRUST L.J. 207, 207 (2003); see also Lawrence Summers, Competition Policy in the New Economy, 69 ANTITRUST L.J. 353, 358 (2001) (" $[I]$ t needs to be remembered that the goal is efficiency, not competition. The ultimate goal is that there be efficiency.").

29. Data of which cases have had public merger enforcement actions brought by the Federal Trade Commission from fiscal year 2000 to the second quarter of fiscal year 2019. FTC Merger Enforcement Actions, DATA CATALOG, https://catalog.data.gov/dataset/ftc-merger-enforcementactions [https://perma.cc/W2VP-DQMD] (last updated Apr. 5, 2019). Data of which cases have been investigated by the U.S. Department of Justice, Antitrust Division, filtered for "Horizontal Merger" violations. Antitrust Case Filings, DeP'T OF JustiCE (last visited Feb. 13, 2020), https://www .justice.gov/atr/antitrust-case-filings?f $\% 5 \mathrm{~B} 0 \% 5 \mathrm{D}=$ field_case_violation $\% 3 \mathrm{~A} 7066$ [https://perma.cc /45SC-M45 4]. For both these data, year 2019 was excluded from the analysis as it had not concluded at the time of writing this paper. The data on merger enforcements from the Antitrust Division goes back much further, and therefore any analysis using text mining prior to year 2000 corresponds to the Department of Justice's enforcement only. 
mining allows for text that already exists - in this particular case, in the form of memorandum opinions - into data frames that can be manipulated, summarized, and visualized in such ways to provide us insights in the form of patterns. ${ }^{30}$ Mauro La Noce et al. applied a similar concept of text mining antitrust cases to detect patterns in Italian antitrust policy over time. $^{31}$ To my knowledge, this is the first paper to apply text mining techniques to U.S. antitrust cases.

I would like to start this historic background with a word cloud (Figure 1) perspective on the cases that will be cited in this Part. The words that are more frequently encountered in the union of those cases can be seen below, where words that appear more frequently have larger fonts.

\section{Figure 1: Word CLOUd OF MOST COMMON WORDS IN SELECTED ANTITRUST CASES FROM 1962-2018}

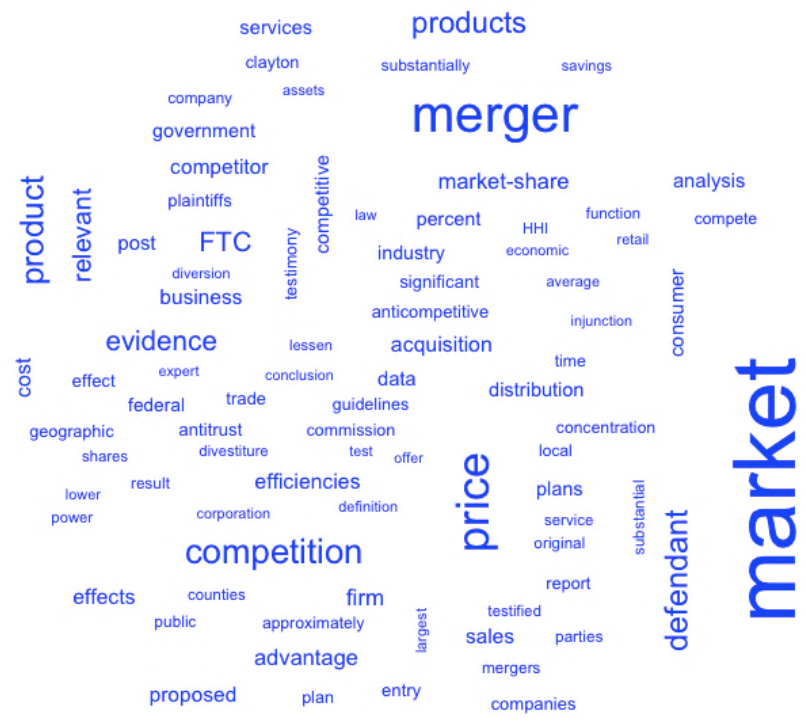

The most common words are, in and of themselves, already very telling of the paths antitrust analyses have taken. The relevant statutory provisions in merger analysis include Section 7 of the Clayton Act, which prohibits mergers if "in any line of commerce or in any activity affecting

30. See Julia Silge \& David Robinson, Text Mining with R: A Tidy Approach (2017), https://www.tidytextmining.com (discussing the text mining data mining method and relevant case studies).

31. Mauro La Noce et al., Merger Control in Italy 1995-2003: A Statistical Study of the Enforcement Practice by Mining the Text of Authority Resolutions, 13 INT'L J. ECON. BUS. 307 (2006). 
commerce in any section of the country, the effect of such acquisition may be substantially to lessen competition, or to tend to create a monopoly." 32 This has been historically interpreted as the need to establish product and geographic market definition. It is no surprise that the most common word in all the cases is market, while product and geographic are not far behind. Other words are still somewhat related to these concepts of market definition, such as retail, industry, sales, local, and counties. Another set of key words involve the basis on which these analyses and decisions are made regarding merger proposals, such as expert, evidence, testimony, data, assets, analysis, etc.

In the United States, the Sherman Antitrust Act, and its expansion with the Clayton Act, are the main statutes governing mergers and acquisitions that substantially reduce market competition. ${ }^{33}$ In 1950, the CellerKefauver Amendment reformed and strengthened the Clayton Act and marked an era of antitrust that was significantly more hostile towards mergers. ${ }^{34}$ This can be seen in Supreme Court decisions such as Brown Shoe Co. v. United States ${ }^{35}$ in 1962 and United States v. Von's Grocery Co. ${ }^{36}$ in 1966, in which the Court assumed almost a per se rule of illegality on mergers in concentrated industries. Additionally, in both cases, the Court noted a significant concern with the protection of small competitors in these industries as a means to protect competition, even if the merger would conceivably be beneficial to consumers. ${ }^{37}$ In Brown Shoe, the Court concluded:

The retail outlets of integrated companies, by eliminating wholesalers and by increasing the volume of purchases from the manufacturing division of the enterprise, can market their own brands at prices below those of competing independent retailers. Of course, some of the results of large integrated or chain operations are beneficial to consumers. Their expansion is not rendered unlawful by the mere fact that small independent stores may be adversely affected. It is competition, not competitors, which the Act protects. But we cannot fail to recognize Congress' desire to promote competition through the protection of viable, small, locally owned business. Congress appreciated that

32. 15 U.S.C. $\S 18$ (2012).

33. See, e.g., Andreas Koutsoudakis, Antitrust More Than a Century After Sherman: Why Protecting Competitors Promotes Competition More Than Economically Efficient Mergers, 34 U. DAYTON L. REV. 223, 231-39 (2009).

34. See, e.g., id. at $239-40 ; 15$ U.S.C. $\S 18$.

35. 370 U.S. 294 (1962).

36. 384 U.S. 270 (1966).

37. Brown Shoe Co., 370 U.S. at 344 (deciding the Court should defer to the legislative intent behind the adoption of antitrust legislation); Von's Grocery Co., 384 U.S. at 282-83 (1966) (Stewart, J. dissent) (disagreeing that the per se rule adopted by the majority complies with the legislative purpose of the relevant acts and amendments). 
occasional higher costs and prices might result from the maintenance of fragmented industries and markets. It resolved these competing considerations in favor of decentralization. We must give effect to that decision. ${ }^{38}$

The decision set a precedent that, even if mergers generate sufficient efficiencies that may offset any price increase through gains in market power and pass cost savings onto consumers, these efficiencies may not be used as an antitrust defense. ${ }^{39}$

In 1963, United States v. Philadelphia National Bank established a presumption that mergers involving at least thirty percent of the relevant market were presumptively unlawful, ${ }^{40}$ which in turn, has significantly shaped the way prima facie cases have rested on level and increasing market concentration. ${ }^{41}$ In 1967, FTC v. Procter \& Gamble Co. held that "[p]ossible economies cannot be used as a defense to illegality," which reflects the view of the Agencies at the time, ${ }^{42}$ as we will see expressed in the 1968 Merger Guidelines. ${ }^{43}$ Figure 2 does a term frequency analysis of these early cases, in which we can see that market share and concentration are often mentioned. Procter \& Gamble efficiencies, entry, and barriers are mentioned often, as the concern that gained economies would translate into diminished ability to compete by smaller firms. ${ }^{44}$

Even though the decision to not accept merger efficiencies as an antitrust defense has never been repealed by the Supreme Court, this is mostly because, since these early decisions, the Court has not had an occasion to revisit the issue of whether efficiencies can be used as a procompetitive argument. ${ }^{45}$ Antitrust policy has changed its approach since then, as explained in the subsequent paragraphs.

38. Brown Shoe Co., 370 U.S. at 344.

39. See generally Kenneth S. Carlston, Introduction: The Meaning and Impact of Brown Shoe Co. v. United States, 1963 WASH. U. L.Q. 153 (1963).

40. 374 U.S. 321 (1963).

41. Herbert Hovenkamp \& Carl Shapiro, Horizontal Mergers, Market Structure, and Burdens of Proof, 127 YALE L.J. 1996, 1996-99 (2018).

42. FTC v. Procter \& Gamble Co., 386 U.S. 568, 580 (1967).

43. U.S. DEP'T OF JUSTICE, 1968 MERGER GUIDELINES (1968), https://www.justice.gov /sites/default/files/atr/legacy/2007/07/11/11247.pdf [https://perma.cc/FR42-Y3E2] [hereinafter 1968 MERGER GUIDELINES].

44. See generally Proctor \& Gamble Co., 386 U.S. 568.

45. An argument can be made that the Court in Cargill, Inc. v. Monfort of Colorado, Inc. implicitly repealed Procter \& Gamble, since in the case efficiencies permitted the firm to cut prices to consumers, and " $[\mathrm{t}] \mathrm{o}$ hold that the antitrust laws protect competitors from the loss of profits due to such price competition would, in effect, render illegal any decision by a firm to cut prices in order to increase market share. The antitrust laws require no such perverse result." 479 U.S. 104, 116 (1986). 
FIGURE 2: EARLY CASES AND WORD FREQUENCY ${ }^{46}$

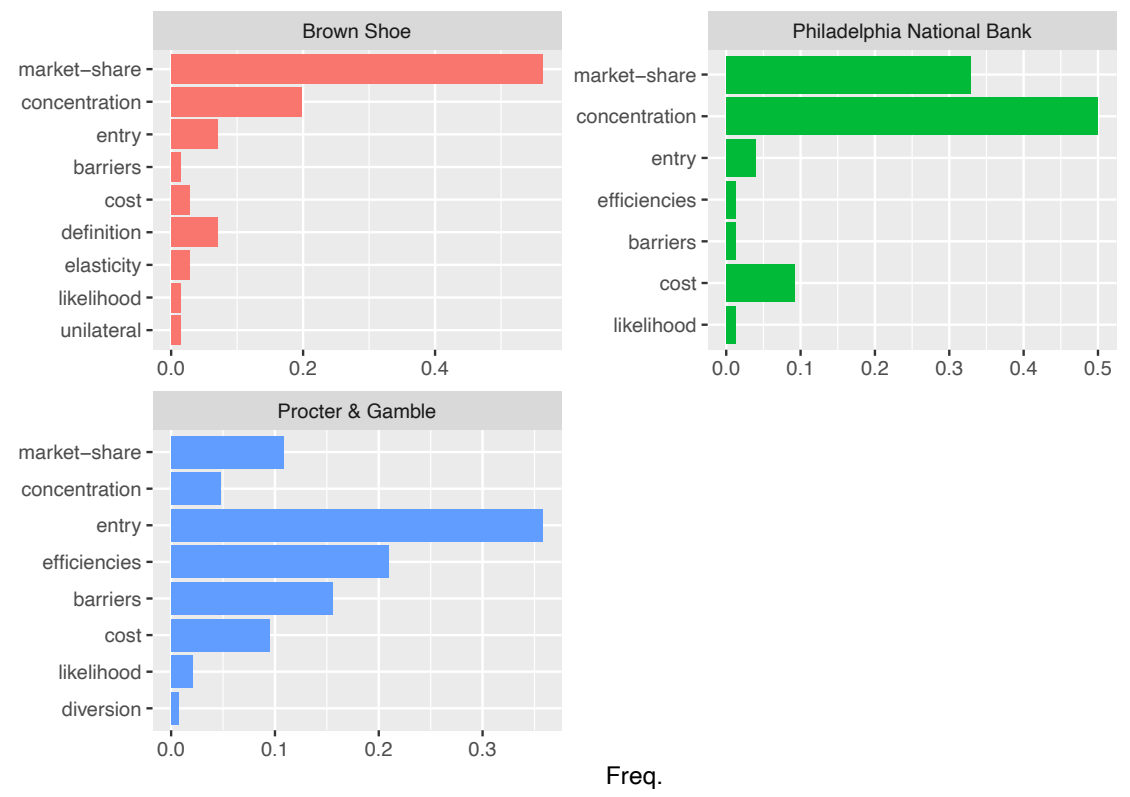

The first Merger Guidelines date from 1968 and comprised both horizontal and vertical mergers. ${ }^{47}$ Economies were not taken under consideration " $[\mathrm{u}]$ nless there [were] exceptional circumstances." ${ }^{, 48}$ In a horizontal merger context, this reluctance in accepting economies as a defense is due to, among other reasons, the possibility of achieving the same economies through "internal expansion" absent a merger ${ }^{49}$ and the "difficulties in accurately establishing the existence and magnitude of economies claimed for a merger." 50 In a vertical merger context, some exception is given to industries that have experienced a "trend toward vertical integration" and "will result in significant economies of production or distribution unrelated to advertising or other promotional economies." ${ }^{51}$ Although, reluctance absent this exception is similarly present due to the belief that most of these efficiencies could be achieved through some "internal expansion into the supplying or purchasing

46. Brown Shoe Co., 370 U.S. 294; Phila. Nat'l. Bank, 374 U.S. 321; Procter \& Gamble, 386 U.S. 568.

47. See 1968 MERGER GUIDELINES, supra note 43.

48. Id. $\S$ I.10, II.16.

49. Id. § II.16.

50. Id. $\S \mathrm{I} .10$.

51. Id. § II.14.a. 
market"; whenever they are not possible, due to significant barriers to entry, the Department of Justice would likely not interfere with the merger. ${ }^{52}$ In the context of conglomerate mergers, a similar "internal expansion" justification is given. ${ }^{53}$

A significant change in merger enforcement occurred with the HartScott-Rodino Antitrust Improvements Act of 1976 (HSR Act), ${ }^{54}$ which requires the parties to potential merger deals above a certain value to notify the Agencies prior to the deal consummation, allowing merger review to be much more prophylactic - it is more efficient to prevent a merger that may generate anticompetitive effects than to attempt to remedy or minimize the resulting harm of a merger that has already occurred.

The 1980s was a period of deep change for antitrust policy, especially regarding the tradeoff between economic efficiency and limiting large corporations in the attempt to preserve consumer welfare. ${ }^{55}$ Such changes provoked a latent need for better quantitative methods and clear concepts to more clearly and coherently conduce antitrust policy.

The second Merger Guidelines, which date from 1982, provided a significant paradigm shift by stating that "[i]n the overwhelming majority of cases, the Guidelines will allow firms to achieve available efficiencies through mergers without interference from the Department." ${ }^{, 56}$ This apparent gain of trust comes with a warning, that "[p]lausible efficiencies are far easier to allege than to prove," 57 requiring "convincing evidence that the merger will produce substantial cost savings" from various sources "and that equivalent results could not be achieved within a comparable period of time through internal expansion or through a merger that threatened less competitive harm." 58

The 1982 Merger Guidelines were relatively short-lived; the Department of Justice soon revised and approved the 1984 Merger Guidelines. ${ }^{59}$ The principles from the 1982 Guidelines are mostly present in the 1984 Merger Guidelines, although some of the ambiguous language

52. Id. § II.16.

53. Id. § III. 18.

54. 15 U.S.C. $\S 18 \mathrm{a}(2018)$.

55. Eleanor M. Fox, Modernization of Antitrust: A New Equilibrium, 66 CORNELL L. REV. 1140, 1140 (1981).

56. See U.S. DeP'T OF Justice, 1982 Merger Guidelines § V.1.A. (1982), https:// www.justice.gov/sites/default/files/atr/legacy/2007/07/11/11248.pdf [https:/perma.cc/RP35-K8FS] [hereinafter 1982 MERGER GUIDELINES].

57. Id.

58. Id. at n.53.

59. U.S. DeP'T OF Justice, 1984 MERGER Guidelines $§ 3.5$ (1984), https://www.justice.gov /sites/default/files/atr/legacy/2007/07/11/11249.pdf [https://perma.cc/M4XY-RNV4]. 
was made clearer. We encounter the statement that " $[t]$ he primary benefit of mergers to the economy is their efficiency-enhancing potential, which can increase the competitiveness of firms and result in lower prices to consumers," which conveys a very positive attitude towards efficiency claims. ${ }^{60}$ The 1984 Merger Guidelines also elaborated on an extensive list of sources for "cognizable efficiencies," while averting that it "will reject claims of efficiencies if equivalent or comparable savings can reasonably be achieved by the parties through other means." ${ }^{1}$

In 1991, the Eleventh Circuit took a significant step in FTC v. University Health, Inc., in which it acknowledged that significant mergergenerated efficiencies, if substantiated, could result in a rebuttal of a prima facie case of illegality. ${ }^{62}$

FIGURE 3: 1991-2000 CASES AND WORD FREQUENCY ${ }^{63}$
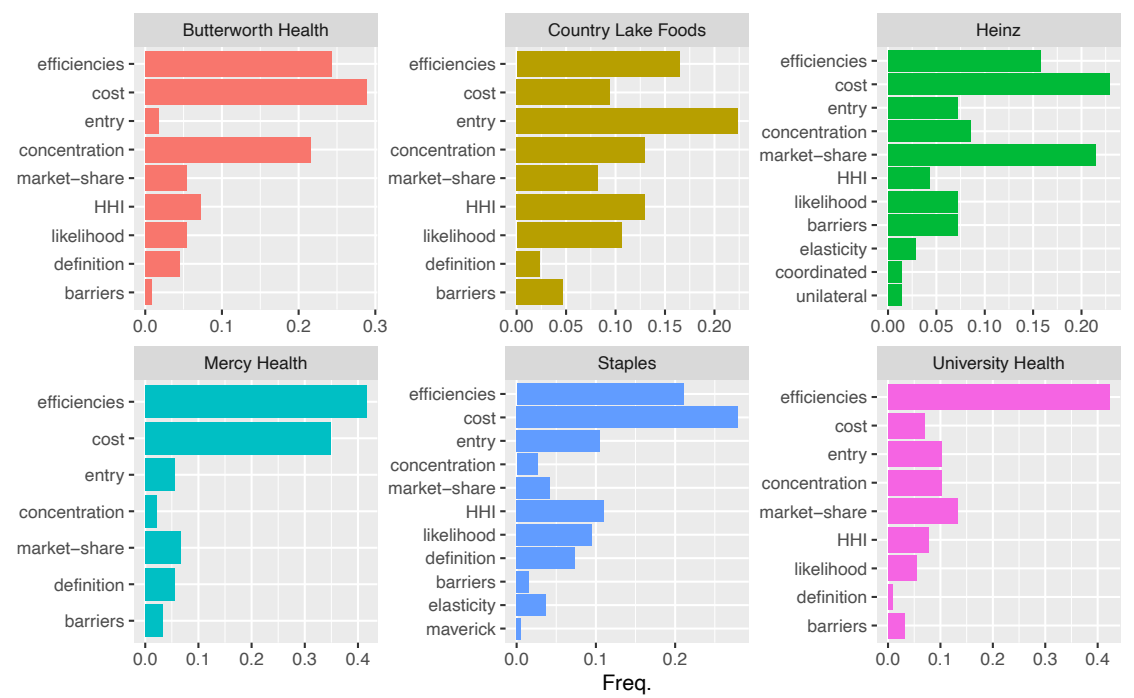

In 1992, the Agencies established the first Horizontal Merger Guidelines, which kept the same verbiage as the 1984 Merger

\section{Id.}

61. $I d$.

62. 938 F.2d 1206, 1221 (11th Cir. 1991).

63. FTC v. Butterworth Health Corp., 946 F. Supp. 1285 (W.D. Mich. 1996); United States v. Country Lake Foods, Inc., 754 F. Supp. 669 (D. Minn. 1990); FTC v. H.J. Heinz Co., 246 F.3d 708 (D.C. Cir. 2001); United States v. Mercy Health Servs., 902 F. Supp. 968 (N.D. Iowa 1995); FTC v. Staples, 970 F. Supp. 1066 (D.C. Cir. 1997); FTC v. Univ. Health, Inc., 938 F.2d 1206 (11th Cir. 1991). 
Guidelines. ${ }^{64}$ Its review in 1997 substantially elaborated and extended the section on efficiencies, by explicitly showing how efficiencies relate to topics from other sessions-such as coordinated and unilateral effects, market concentration as shown by the Herfindahl Hirschman Index (HHI), and potential entry. ${ }^{65}$ It also coined the term merger-specific efficiencies, which replaced the long description in previous documents; and it took a stand by stating that they "found that certain types of efficiencies are more likely to be cognizable and substantial than others," citing favorably "shifting production among facilities formerly owned separately, which enable the merging firms to reduce the marginal cost of production." Figure 3 shows a significant increase in the frequency of efficiencies in these cases.

In the 2010 Guidelines, the optimist approach in the past decades was replaced with perhaps a little more caution, as indicated in the statement that "[c]ompetition usually spurs firms to achieve efficiencies internally. Nevertheless, a primary benefit of mergers to the economy is their potential to generate significant efficiencies and thus enhance the merged firm's ability and incentive to compete."67 The 2010 Guidelines placed significant emphasis on the expectations for cognizable efficiencies, while recognizing they will "consider whether cognizable efficiencies likely would be sufficient to reverse the merger's potential to harm customers in the relevant market." 68 The focus shifted from efficiencies that reduce marginal cost to acknowledge that efficiencies can "operate along multiple dimensions," and even mentions potential efficiencies in innovation that may not be reflected in "short-term pricing." ${ }^{69}$ However, they equally recognized that some types of efficiencies are more likely to be cognizable, with the same example given in 1997 Guidelines. ${ }^{70}$ Figure 4 shows method keywords that have played a significant role in recent cases. Figure 5 shows the most common bigram directional associations in antitrust cases, which efficiencies are most commonly associated with significant and defense.

\footnotetext{
64. See U.S. DeP'T OF Justice \& Fed. Trade Comm’n, Horizontal Merger Guidelines $§ 4$ (1992).

65. See U.S. Dep't of Justice \& Fed. Trade Comm'n, Horizontal Merger Guidelines § 4 (1992, rev. 1997), https://www.ftc.gov/sites/default/files/attachments/merger-review/hmg.pdf [https://perma.cc/Y53W-LYQR].

66. $I d . \S 4 \mathrm{n} .35$.

67. See 2010 Horizontal MERger Guidelines, supra note 4, $§ 10$.

68. Id.

69. Id.

70. $I d$.
} 
FIGURE 4: POST-2000 CASES AND WORD FREQUENCY ${ }^{71}$

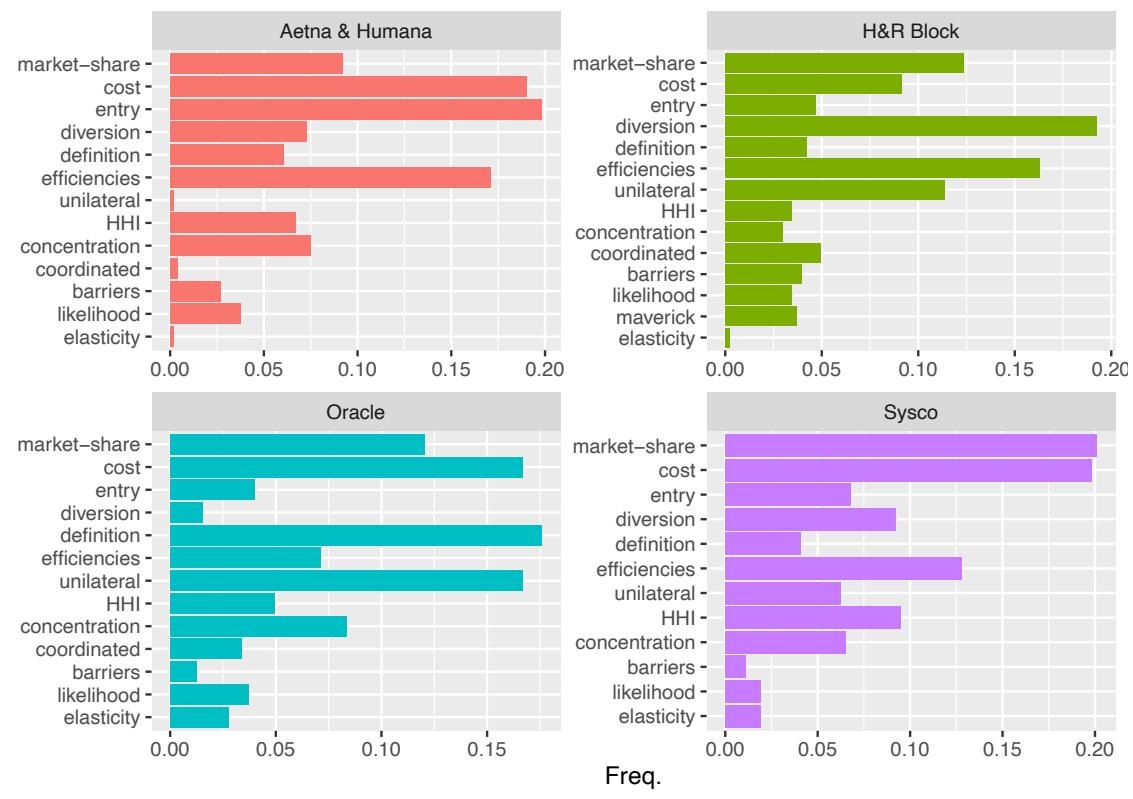

71. United States v. Aetna, Inc., 240 F. Supp. 3d 1 (D.D.C. 2017); United States v. H\&R Block, Inc., 833 F. Supp. 2d 36 (D.D.C. 2011); United States v. Oracle Corp., 331 F. Supp. 2d 1098 (N.D. Cal. 2004); FTC v. Sysco Corp., 113 F. Supp. 3d 1 (D.D.C. 2015). 
FIGURE 5: TERM FREQUENCY OF “EFFICIENCIES” IN SELECTED ANTIRUST CASES OVER TIME

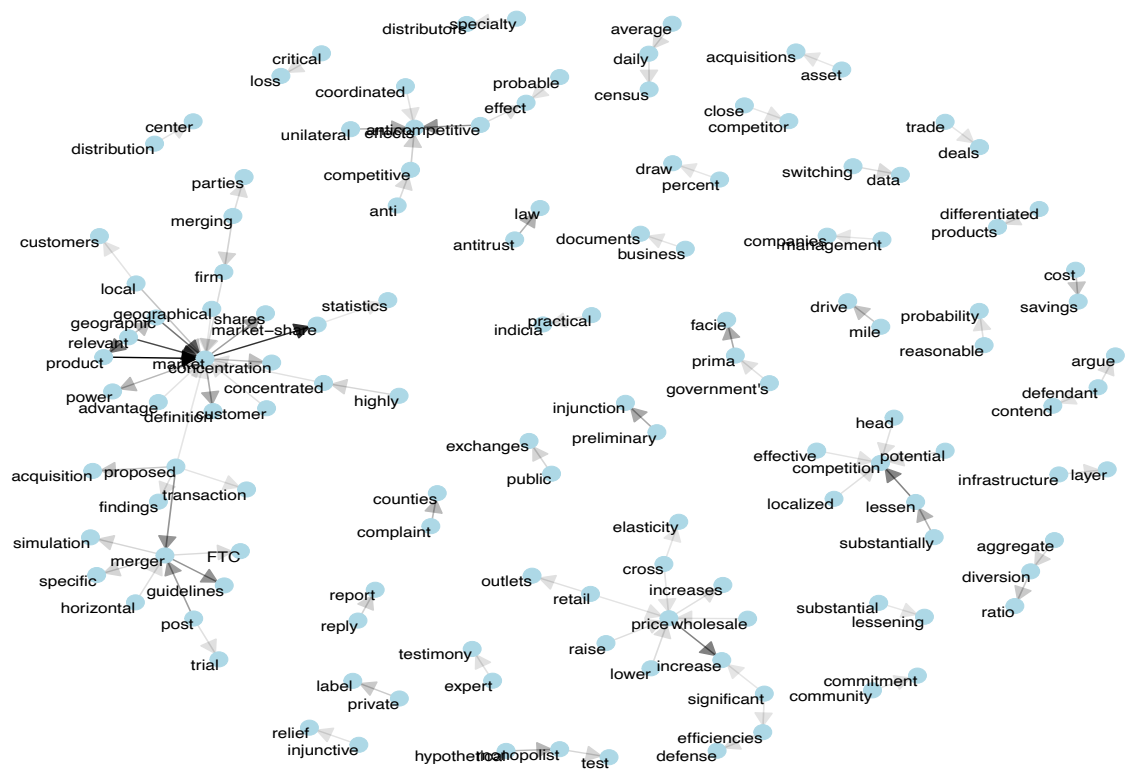

FiguRE 6: MOST COMMON BIGRAM DiRECTIONAL ASSOCIATIONS IN SELECTED ANTITRUST CASES

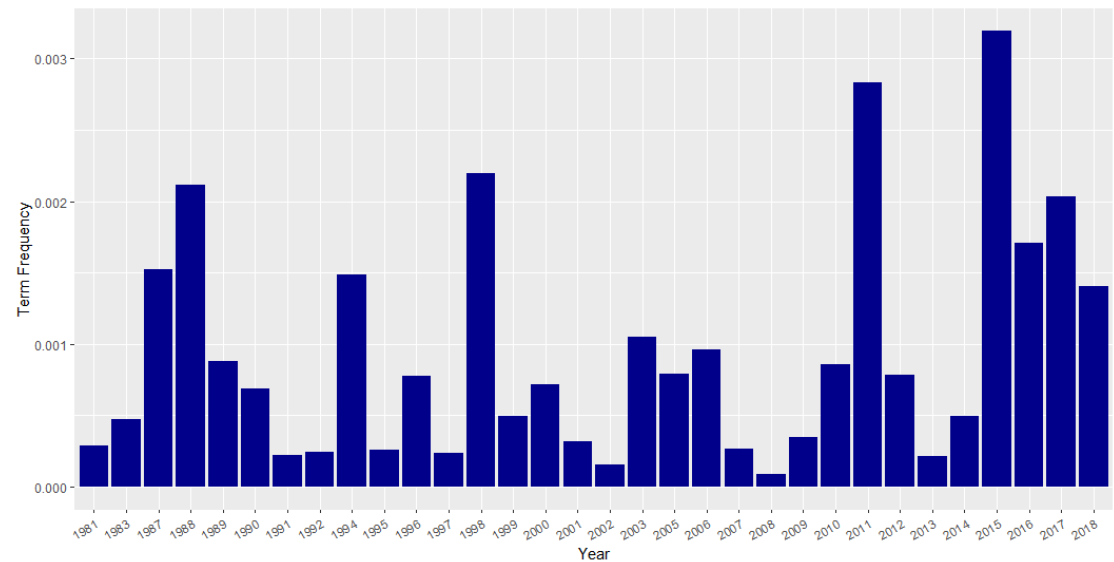


An interesting measure that shows the variation of efficiency claims over time with term frequency, and term frequency times inverse document frequency, can be seen in Figures 6 and 7, respectively. Term frequency is self-explanatory, while inverse document frequency is a measure of a term's importance within a document. ${ }^{72}$ We can see an increase in efficiency claims following the incorporation of more descriptive efficiency requirements in the 1984 Merger Guidelines, and similarly with the actualization of the Horizontal Merger Guidelines in 1997. There is also a significant increase of the term in recent years. Notice that increases in the term do not necessarily mean acceptance of those defenses, but rather the mentioning of those in court. Another caveat of this measure is that if there is a decrease in the number of merger cases in general, this will also be translated as a smaller term frequency, and variations may not account for just variations of merger analysis or defense strategies.

\section{FIGURE 7: TERM FREQUENCY TIMES INVERSE DOCUMENT FREQUENCY OF “EFFICIENCIES” In SELECTED ANTIRUST CASES OVER TIME}

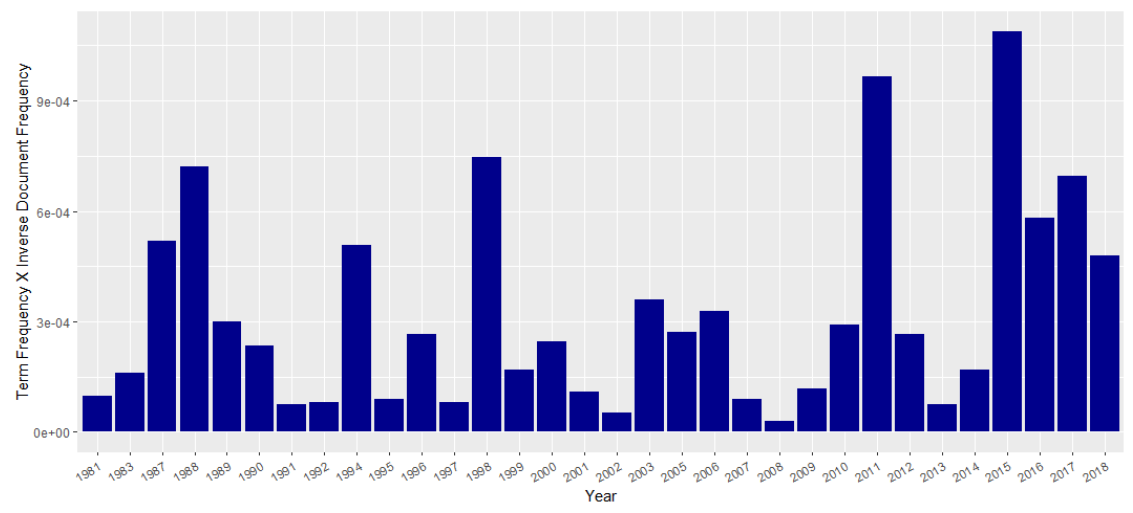

Despite this saga of varying understanding and acceptance of merger efficiencies in antitrust framework, a latent question is "whether efficiencies to date are still recognized more in theory than in practice." 73 The ability to estimate ex ante merger specific efficiencies still poses a

72. Calculation of inverse document frequency is done by the logarithm of the ratio between the number of cases and the number of cases containing the term in question. The more often a term appears in a case among the pool of cases, the more important this term ought to be in this particular case. The product then is a good measure of the overall relevance of a term in a pool of cases (in this case, in each year). See, e.g., Silge \& Robinson, supra note 30, ch. 3; NATURAL LANGUAGE Processing And TeXt Mining 5-6 (Anne Kao \& Stephen R. Poteet eds., 2007).

73. Shelanski, supra note 24 , at 464 . 
major hurdle in its admission as an antitrust defense.

Figure 8: HSR ACT PRE-MERger NotifiCATIONS AND HSR ACT

INVESTIGATIONS INITIATED (2007-2016)

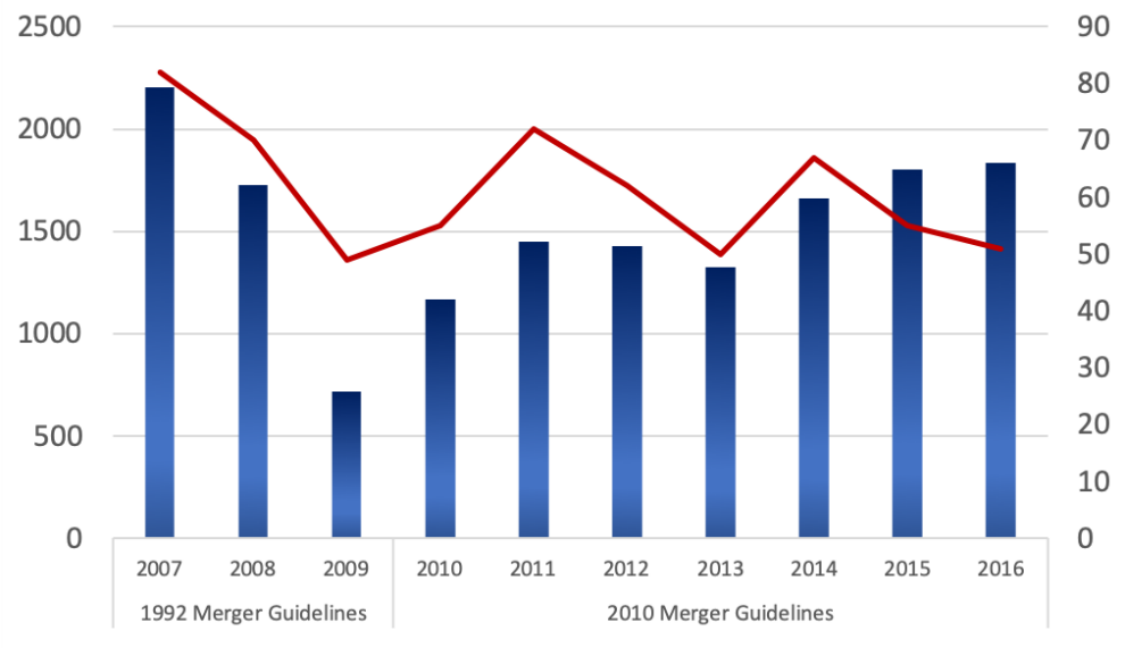

Hart-Scott Rodino Premerger Notifications —HSR Investigations Initiated

Figure 8 shows, over a decade, the volume of HSR Act pre-merger notifications and the volume of investigations initiated in the United States. ${ }^{74}$ It becomes clear that the volume of actual investigations resulting from notifications is fairly low. ${ }^{75}$ One could ask whether merger-induced cost reductions should be taken under consideration as a potential defense, and if so, in which stage. Part III discusses the use of market concentration screening techniques, such as the HHI, in merger analysis, which inherently do not account for merger efficiencies.

\section{MERGER EFFICIENCIES AND MARKET CONCENTRATION}

A common practice in merger screening is to look at market concentration measures, with the premise that more concentrated markets will likely be more anticompetitive, tending to harm consumers. This can be seen in the statement, "Other things being equal, concentration affects

74. Data regarding annual HSR Act pre-merger notifications and investigations is publicly available and can be found on the Federal Trade Commission's website under the Data Set Name "HSR Transactions Filings and Second Requests by Fiscal Year." Data Sets, Fed. TRAdE Comm'N, https://www.ftc.gov/site-information/open-government/data-sets [https://perma.cc/E3JZ-69Q5] (last visited Mar. 26, 2020).

75. See id. 
the likelihood that one firm, or a small group of firms, could successfully exercise market power." 76 This sentiment of skepticism towards market share and market concentration has somewhat evolved over time, as shown in Part II, and reflects the holistic nature of our contemporary merger review: "Market concentration is often one useful indicator of likely competitive effects of a merger. ... Market shares may not fully reflect the competitive significance of firms in the market or the impact of a merger. They are used in conjunction with other evidence of competitive effects." ${ }^{, 77}$ Despite its popularity in merger screening and analysis, it is important to verify whether market concentration measures in general, and the HHI in particular, are good tools to determine likelihood of harm arising from mergers in the presence of efficiencies. Going back to Williamson, described in detail in Part I, the welfare impact of a simple case of mergers in the presence of efficiencies is ambiguous, due to two effects happening simultaneously: (1) increased concentration that is then translated into additional market power; and (2) cost-savings, which are partially passed through to consumers. ${ }^{78}$ By relying heavily on market concentration measures, one can observe the first driver of welfare changes, but not the second. ${ }^{79}$

Doing a brief recap of measures of market concentration in consolidation analyses, we can see that in the 1968 Merger Guidelines until the beginning of the 1980's (prior to the 1982 Merger Guidelines) these analyses were conducted by observing a four firm concentration ratio. ${ }^{80}$ This test, called the "top 4" or "CR4," was the most widely-used method to infer market concentration. ${ }^{81}$ Despite its intuitive nature and clear message, this test has two major caveats. ${ }^{82}$ The CR4 does not take into account the size of each firm nor the number of firms in the market. ${ }^{83}$ From both microeconomic theory and empirical studies, it is acknowledged that firms of different sizes have distinct competitive

76. 1982 MERGER GUIDELINES, supra note 56, § III.A.

77. 2010 HORIZONTAL MERGER GUIDELINES supra note 4 , $\$ 5.3$.

78. See Williamson, The Welfare Tradeoffs, supra note 1 at 18-36.

79. Id. at 33-34.

80. See 1968 MERGER GUIDELINES, supra note 43.

81. See David S. Weinstock, Using the Herfindahl Index to Measure Concentration, 27 ANTITRUST BULL. 285, 285 (1982). Concentration Ration for the Top 4 firms (CR4) is a simple sum of the market share of the four largest firms within an industry. See id. This test shows the percentage of the transactions of an industry retained by the largest four firms. Id. There is nothing special about the number four apart from the fact it was commonly used. More generally there is the CRX, or Concentration Ration for the Top X firms. See id. at 285 n.1.

82. See id. at 285 .

83. Id. 
dynamics. ${ }^{84}$ It is then necessary to provide policymakers and market analysts with a reliable quantitative method that better portrays the competitive incentives within a market. When determining market concentration, it is insufficient to show just the percent of a market served by a certain number of firms because, ultimately, the information necessary is the incentives of competitive behavior or the lack thereof within a particular industry.

The 1980s was a period of deep change for antitrust policy, especially when dealing with the tradeoff between limiting large corporations in the attempt to preserve consumer welfare and economic efficiency. ${ }^{85}$ Such changes provoked a latent need for better quantitative methods and clear concepts to more coherently conduce antitrust policy. ${ }^{86}$ William Baxter reinforces the idea that nonefficiency type goals tend to be intractable, which makes it hard to assess their success, and economic efficiency would therefore be the only workable standard from which the guidelines could be derived and any attainability of goals assessed ${ }^{87}$

The proposal and adoption of the HHI in the beginning of the $1980 \mathrm{~s}$ inspired many to evaluate the impacts of such analytical instruments in conducting antitrust policy. ${ }^{88}$ Stephen Calkins evaluated the use of the $\mathrm{HHI}$ as the new merger guideline, and highlighted some of the features it brings that are advantageous when compared with the CR4, such as its responsiveness to asymmetry in market shares. ${ }^{89}$ The HHI is also much more comprehensive than the $\mathrm{CR} 4$, since its computation includes the market share of every firm within the market. ${ }^{90}$ The HHI then provided a considerably simpler tool to measure the impact of a horizontal merger based on the resulting increase in HHI.

84. See generally Miguel C. Manjón-Antolín, Firm Size and Short-Term Dynamics in Aggregate Entry and Exit, 28 INT'L J. INDUS. ORG. 464 (2010); Kim Dong-Hyeon et al., Firm Structure, Firm Size and Industry Growth, 41 InT'L REV. ECON. \& Fin. 23 (2016); Abongeh Tunyi, Firm Size, Market Conditions and Takeover Likelihood, 18 REV. ACCT. \& FIN. 483 (2019).

85. See, e.g., Eleanor M. Fox, Modernization of Antitrust: A New Equilibrium, 66 CorNELL L. REV. 1140, 1141-46 (1981) (discussing the emergence and evolution of antitrust law from the 1960s to the early 1980 s).

86. See Daniel L. Rubinfeld \& Peter O. Steiner, Quantitative Methods in Antitrust Litigation, 46 L. \& CONTEMP. PROBS. 69 (1983).

87. See William F. Baxter, Responding to the Reaction: The Draftsman's View, 71 CALIF. L. REV. 618 (1983).

88. For a complete review of the development and naming of the Herfindahl Index, see Weinstock, supra note 81.

89. Stephen Calkins, The New Merger Guidelines and the Herfindahl-Hirschman Index, 71 CALIF. L. REV. 402, 404 (1983). The same advantage, however, brings another complication, since small errors in measurement of an industry's market share will be amplified by the index and may yield wrongful judgements regarding mergers. $I d$.

90. Id. at 411 . 
The HHI was adopted in 1982 as the standard form of calculating market concentration for merger analysis purposes. ${ }^{91}$ This methodology is still used today, as it is shown in the 2010 Guidelines, where $s_{i}$ is the market share of firm $i .^{92}$

$$
H H I=\sum_{i=1}^{n} s_{i}^{2}
$$

A naïve change in HHI due to a merger is done with the simplifying assumption that the resulting firm from the merger would maintain the sum of the market share of the two previously independent merging parties, while having no redistribution of market share among the other firms in the market. This results in a simple formula of change in HHI due to merger $(\triangle H H I)$ as well as on how to estimate post-merger HHI ex ante as $H H I_{\text {post }}=H H I_{\text {pre }}+\Delta H H I .{ }^{93}$ Let the market shares for merging parties $A$ and $B$ be respectively $s_{A}$ and $s_{B}$.

$$
\Delta H H I=\left(s_{A}+s_{B}\right)^{2}-s_{A}^{2}-s_{B}^{2}=2 s_{A} s_{B}
$$

Nathan Miller et al. tested the accuracy of the HHI as a merger screening tool in a variety of merger scenarios through Monte Carlo experiments, and they make a compelling argument that HHI can in many cases be a good indicator. ${ }^{94}$ With existing barriers to entry, market power is the ability of firms to price above the competitive level and restrict output. The more firms there are in the market, and/or the higher the degree of substitutability between products, the harder it is for firms to unilaterally restrict output. ${ }^{95}$

Jéssica Dutra and Tarun Sabarwal document the need to include model-based efficiencies in the estimate of unilateral effects, such as upward pricing pressure and first order approximation. ${ }^{96}$ By construction, a naïve post-merger HHI will not account for any potential efficiencies that may arise from a transaction.

In this paper, I test the accuracy of HHI as a merger screening tool in the presence of marginal cost reducing merger-specific cost complementarities. To do so, I use a Monte Carlo study in which industries are randomly generated to span a wide range of economic

91. Id. at 402 .

92. See 2010 Horizontal MERGER Guidelines, supra note 4.

93. Id. $\S 5.3 \mathrm{n} .9$ (providing examples of this calculation and further explanation).

94. Nathan H. Miller et al., Upward Pricing Pressure as a Predictor of Merger Price Effects, 52 INT'L J. INDUS. ORG. 216, 223-24 (2016).

95. We can see this relationship in Logit demand systems; for example, in which diversion ratios are proportional to market shares.

96. Jéssica Dutra \& Tarun Sabarwal, Antitrust Analysis with Upward Pricing Pressure and Cost Efficiencies, PLOS ONE, Jan. 2020, at 1. 
environments in which a merger might occur. Following Miller et al., I classify mergers generated across five potential categories, as laid down by the 2010 Guidelines: ${ }^{97}$

- Category (i): HHI post-merger is greater than 2500 and HHI change from pre-merger to post-merger is greater than 200 .

- Category (ii): HHI post-merger is greater than 2500, however the change in concentration due to the transaction is greater than 100 , but less or equal to 200 .

- Category (iii): HHI post-merger is greater than 1500 and change in $\mathrm{HHI}$ is above 100.

- Category (iv): Resulting post-merger market is unconcentrated (i.e., $\mathrm{HHI}<=1500$ ).

- Category (v): Change in concentration due to merger is of less than 100.

The above categories are not mutually exclusive, but they provide decreasing likelihood of being investigated by the Agencies. Therefore, in the remainder of this paper, I will use the allocation of potential merger cases into these categories as criteria for whether the Agencies would investigate such a merger, and thus infer the quality of HHI as a merger screening tool in the presence of merger efficiencies.

To investigate the validity and efficacy of $\mathrm{HHI}$ as a merger screening tool in the presence of merger efficiencies in multiple market structures, I suppose a market structure for each industry, which may contain four, six, or eight firms competing in prices with differentiated goods. Each firm produces a single output and industry equilibrium is Bertrand-Nash. ${ }^{98}$ The steps for data generating process and equilibria computation are as follows:

1. Start with a market for four firms.

2. Market shares are randomly drawn for each of the firms and an outside good. The actual market shares that are used in the process are normalized to aggregate to one for the market in question. The margin for the first firm is randomly drawn with support [0.2,0.8].

3. The parameters for the interactive term in the cost structures are randomly drawn with support $[0,1]$.

4. Given the market shares and margins, it is possible to calibrate a Logit demand system, and thus, demand elasticities in the pre-

97. See Miller et al., supra note 94; see also 2010 HoRIZONTAL MERGER GUIDELINES, supra note $4, \S 5$.

98. See Dutra \& Sabarwal, supra note 96 (providing equivalent method calibration details of the Monte Carlo simulations). 
merger equilibrium. Notice that the demand system is such that its parameters are chosen to rationalize the data drawn in the previous steps. In this study, consumer substitution behavior is proportional to market shares. These parameters are identified exactly given market shares, prices, and a single margin.

5. Once the Logit demand system is obtained, it is possible to calibrate the remaining demand functional forms (Log-Linear, Linear and Almost Ideal) such that they are compatible with the Logit demand elasticities. Similarly, the demand systems' parameters are perfectly identified given market shares, prices, and Logit demand elasticities.

6. In each draw, two firms go through a merger. Post-merger equilibrium prices are computed as well as Herfindahl Hirschman Index. Mergers are classified into five categories, as laid out in the 2010 Guidelines. $^{99}$

7. Repeat these steps until 3,000 draws of data are obtained.

8. Repeat this process for six and eight firms' market structures.

This Monte Carlo study generates 72,000 mergers to be evaluated (3 market structures, 4 demand systems, 2 cost structures, 3,000 draws of data each). The market structure investigated involves a merger from four to three players, while the subsequent sets involve mergers from six to five, and from eight to seven players respectively. The descriptive statistics for these can be found in Tables 2, 3, and 4. Part IV discusses the results from the study described in this Part.

\section{RESULTS}

The results from the Monte Carlo data generating process described in the Part III are described here. As to be expected, the margin is relatively similarly distributed in all market structures, as it follows the same data generating process. Thus, the differences across market structures are generated by the distinct market structures themselves, rather than initial diverging margin conditions. The median four-firm market structure is moderately concentrated pre-merger and highly concentrated post-merger; the median six-firm market structure is moderately concentrated both premerger and post-merger; and the median eight-firm market structure is unconcentrated pre-merger and just over the moderately concentrated threshold post-merger. Thus, it is clear that the chosen structures span a significant portion of the critical potential merger environments that

99. See 2010 Horizontal MERGER Guidelines, supra note 4, $§ 5$. 
should be explored.

Figure 9 shows the distribution kernels of pre- and post-merger concentrations of the markets generated in the Monte Carlo study. The first row corresponds to the data generating process with a four-firm market structure, while the subsequent rows are for six and eight firms respectively. As to be expected, randomly drawing industries with four firms generate much more concentrated markets than their counterparts with a greater number of firms. As HHI is used as a market concentration measure - as well as one of the determinants in the likelihood of investigation by the Agencies - the pool of industries that was randomly generated in this Monte Carlo study make a compelling sample to study this relationship.

Figure 9: PRE- AND POST-MERGER HHI Distribution
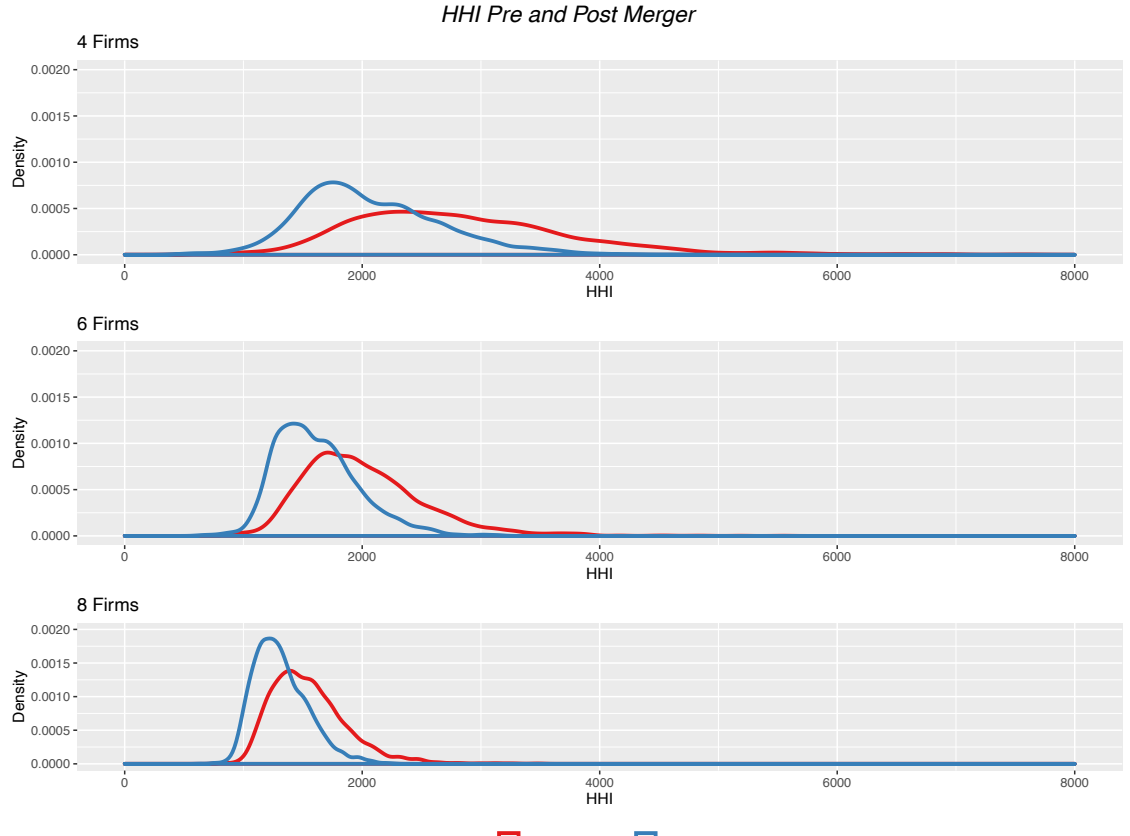

Market $\square$ Post-Merger HHI $\square$ Pre-Merger HHI

Cost reductions, given by a Generalized Leontief functional form, provide merger efficiencies that are a function of the ratio of production levels for the formerly independent firms, while Quadratic functional form provides that is proportional to the other firm's production. The former will provide higher magnitude cost reductions than the latter, given the same efficiency parameter. Across all market structures, the efficiencies generated through Generalized Leontief can, at the median, more than compensate for the incentive to raise prices due to consolidation, while 
Quadratic generated efficiencies still allow for price increase. Also notice that for comparable efficiencies, market structures with more firms will tend to have smaller price increases (competition motivated by number of firms in the market still reduces the likelihood that firms can increase prices profitably). This price correlation seems to suggest that market concentration can be a useful indicator of whether competition agencies should be concerned with a proposed merger.

Tracking the categories based on HHI as previously described, the probability that a merger that finds itself in one of these categories may increase price by at least $5 \%$ or $10 \%$ can be found on Tables 4,5 , and 6 . For four firms in a Generalized Leontief cost structure, the probability of a $5 \%$ price increase if a proposed merger falls under category (i) ranges from $30 \%$ to $58 \%$ depending on the demand system, while for Quadratic it ranges from $61 \%$ to $90 \%$. Finding itself in categories (i) through (iii) ranges from $20 \%$ to $54.7 \%$, and from $40 \%$ to $82 \%$, respectively. The ranges hold somewhat constant varying market structures. For a $10 \%$ price increase, the probabilities are slightly more underwhelming. Potential mergers with a Generalized Leontief cost complementarity, that falls under category (i) has probabilities ranging from $16.6 \%$ to $54.3 \%$, while the ones that fall under categories (i) through (iii) have probabilities ranging from $11.5 \%$ to $51.2 \%$ depending on demand curvature. As to be expected, Quadratic cost complementarities have higher likelihood of price increase, due to smaller merger specific efficiencies. This reinforces that idea that market concentration as measured by HHI can indicate effects at least in terms of likelihood of price increases, but the more substantial and significant the merger efficiencies are, the poorer of an indicator it will be. Notice here that we are observing this relationship between concentration and prices from a unique angle: how often mergers that fall under certain HHI categories will translate themselves into actual price increases of at least a certain threshold.

However, one of the fundamental roles of the HHI is to provide a merger screening tool. In the best-case scenario, a merger flagged by the tool as generating potential anticompetitive effects is one that would indeed harm competition if allowed to go through. But as with any tool, being an imperfect measure of reality, this is not always the case. This creates two types of statistical errors. A type I error, also known as a false positive, in this case occurs when the HHI indicates potential for anticompetitive effects in the transaction when, in reality, it would not. A type II error, on the other hand, is one that the HHI would indicate no anticompetitive effects when, in fact, there would be.

Based on each randomly generated market in the Monte Carlo study, 
it is possible to observe how much a price has changed after the merger. In the 2010 Guidelines, there is not a predetermined threshold for a price increase that is deemed anticompetitive. In order to calculate types I and II errors, it is necessary to infer the implicit anticompetitive threshold from the policymakers. In this paper, two thresholds were considered: (1) a 5\% increase, as it is taken as a threshold for market definition as a small but significant and non-transitory increase in price on the hypothetical monopolist test, as described in section 4.1 .3 of the 2010 Guidelines; and (2) a 10\% price increase has been considered by Joseph Farrell and Carl Shapiro, ${ }^{100}$ and Miller et al. ${ }^{101}$

For criteria of whether a merger will be investigated based on levels of HHI, I investigate two different options based on the categories described in Part III, as follows: (1) the proposed merger can be classified in category (i); or (2) the proposed merger can be classified in at least one of categories (i), (ii), or (iii).

This created the possibility of calculating for each market structure, demand system, and cost efficiencies functional form, four values of type I and type II errors. Total error is the simple sum of type I and II statistical errors.

As an example, before we get into the classification of a merger using a merger screening tool and the importance of thresholds in this computation, suppose a merger that has generated a $7.5 \%$ price increase, its resulting post-merger $\mathrm{HHI}$ is of 2750 and $\Delta H H I=125$.

- Under the first combination of criteria, a merger is anticompetitive if it increases price by more than $5 \%$ and a merger belongs to category (i). The merger in question presents a price increase greater than $5 \%$ but it does not belong to category (i). Therefore, it constitutes a false negative.

- Under the second combination of criteria, a merger is anticompetitive if it increases price by more than $10 \%$ and a merger belongs to category (i). The merger in question is then a true negative.

- Under the third combination of criteria, a merger is anticompetitive if it increases price by more than 5\% and a merger belongs to at least one of categories (i), (ii), or (iii). The merger in question is a true positive.

- Under the fourth combination of criteria, a merger is

100. See Joseph Farrell \& Carl Shapiro, Antitrust Evaluation of Horizontal Mergers: An Economic Alternative to Market Definition, B.E. J. THEORETICAL ECON., Jan. 2010, at 1, 12.

101. See Miller et al., supra note 94. 
anticompetitive if it increases price by more than $10 \%$ and a merger belongs at least one of categories (i), (ii), or (iii). The merger in question is a false positive.

It becomes clear that especially for the border cases, it is important to fine-tune both the understanding of which price increase is considered to be anticompetitive, as well as which naïve increases in market concentration will be used as a threshold. Ideally, those will reflect the implicit thresholds from the Agencies. Fortunately, for extreme cases, these fine tunings will not matter as much, and we can get a bigger picture of these likelihoods. The various probabilities are reported on Tables 4, 5, and 6 reflect the shifts in mass from these fringe classifications based on various criteria.

Total errors for first combination of criteria in four firms market structures range from $40-48 \%$ for Generalized Leontief cost complementarities, while being $24-33 \%$ for Quadratic. For our fourth combination of criteria, we have total errors in the magnitude of $50-79 \%$ for Generalized Leontief and $31-77 \%$ for Quadratic. It is clear that in the presence of efficiencies, relying on market concentration measures can be very uninformative about the likelihood of harming consumers as measured by price increases. Even for efficiencies that are not as substantial as the ones from Quadratic cost complementarities, it is clear how many aggregate total errors can be accrued. Similar patterns can be observed in all market structures. 
TABLE 1: DESCRIPTIVE STATISTICS - FOUR FIRMS

\section{Four Firms}

\begin{tabular}{|c|c|c|c|c|c|}
\hline & Median & $10 \%$ & $25 \%$ & $75 \%$ & $90 \%$ \\
\hline \multicolumn{6}{|c|}{ Market Conditions } \\
\hline Market Share & 0.201 & 0.049 & 0.114 & 0.276 & 0.339 \\
\hline Margin & 0.472 & 0.247 & 0.333 & 0.624 & 0.745 \\
\hline \multicolumn{6}{|c|}{ Market Concentration } \\
\hline Pre-Merger & 1976 & 1415 & 1651 & 2430 & 2873 \\
\hline Post-Merger & 2706 & 1801 & 2164 & 3360 & 4041 \\
\hline$\Delta \mathrm{HHI}$ & 648 & 113 & 310 & 1075 & 1520 \\
\hline \multicolumn{6}{|c|}{$\begin{array}{l}\text { Merger Price Effects - Generalized Leontief Cost } \\
\text { Structure }\end{array}$} \\
\hline Logit & -0.020 & -0.319 & -0.122 & 0.038 & 0.123 \\
\hline Linear & -0.038 & -0.224 & -0.112 & 0.022 & 0.101 \\
\hline Log-Linear & -0.081 & -0.651 & -0.363 & 0.183 & 1.072 \\
\hline Almost Ideal & -0.053 & -0.462 & -0.235 & 0.115 & 0.547 \\
\hline \multicolumn{6}{|c|}{$\begin{array}{l}\text { Merger Price Effects - Quadratic Cost } \\
\text { Structure }\end{array}$} \\
\hline Logit & 0.043 & 0.006 & 0.019 & 0.073 & 0.109 \\
\hline Linear & 0.035 & 0.005 & 0.015 & 0.066 & 0.107 \\
\hline Log-Linear & 0.136 & 0.010 & 0.046 & 0.342 & 0.931 \\
\hline Almost Ideal & 0.083 & 0.007 & 0.030 & 0.201 & 0.497 \\
\hline
\end{tabular}


TABle 2: Descriptive STATISTICS - SiX FIRMS

\section{Six Firms}

\begin{tabular}{|c|c|c|c|c|c|}
\hline & Median & $10 \%$ & $25 \%$ & $75 \%$ & $90 \%$ \\
\hline \multicolumn{6}{|c|}{ Market Conditions } \\
\hline Market Share & 0.143 & 0.033 & 0.078 & 0.201 & 0.247 \\
\hline Margin & 0.487 & 0.254 & 0.341 & 0.636 & 0.745 \\
\hline \multicolumn{6}{|c|}{ Market Concentration } \\
\hline Pre-Merger & 1569 & 1233 & 1361 & 1818 & 2076 \\
\hline Post-Merger & 1925 & 1452 & 1649 & 2278 & 2666 \\
\hline$\Delta \mathrm{HHI}$ & 316 & 46 & 137 & 556 & 843 \\
\hline \multicolumn{6}{|c|}{$\begin{array}{l}\text { Merger Price Effects - Generalized Leontief Cost } \\
\text { Structure }\end{array}$} \\
\hline Logit & -0.071 & -0.414 & -0.193 & -0.002 & 0.054 \\
\hline Linear & -0.071 & -0.265 & -0.151 & -0.012 & 0.033 \\
\hline Log-Linear & -0.166 & -0.690 & -0.430 & 0.023 & 0.390 \\
\hline Almost Ideal & -0.113 & -0.508 & -0.297 & 0.013 & 0.223 \\
\hline \multicolumn{6}{|c|}{$\begin{array}{l}\text { Merger Price Effects - Quadratic Cost } \\
\text { Structure }\end{array}$} \\
\hline Logit & 0.021 & 0.001895 & 0.008 & 0.038 & 0.055 \\
\hline Linear & 0.015 & 0.001 & 0.005 & 0.029 & 0.044 \\
\hline Log-Linear & 0.062 & 0.004 & 0.022 & 0.143 & 0.316 \\
\hline Almost Ideal & 0.039 & 0.002 & 0.014 & 0.088 & 0.184 \\
\hline
\end{tabular}


TABLE 3: DESCRIPTIVE STATISTICS - EIGHT FIRMS

Eight Firms

\begin{tabular}{|c|c|c|c|c|c|}
\hline & Median & $10 \%$ & $25 \%$ & $75 \%$ & $90 \%$ \\
\hline \multicolumn{6}{|c|}{ Market Conditions } \\
\hline Market Share & 0.111 & 0.025 & 0.059 & 0.159 & 0.193 \\
\hline Margin & 0.495 & 0.257 & 0.346 & 0.644 & 0.746 \\
\hline \multicolumn{6}{|c|}{ Market Concentration } \\
\hline Pre-Merger & 1280 & 1050 & 1147 & 1451 & 1620 \\
\hline Post-Merger & 1506 & 1196 & 1322 & 1722 & 1960 \\
\hline$\Delta \mathrm{HHI}$ & 186 & 26 & 78 & 350 & 508 \\
\hline \multicolumn{6}{|c|}{$\begin{array}{l}\text { Merger Price Effects - Generalized Leontief Cost } \\
\text { Structure }\end{array}$} \\
\hline Logit & -0.102 & -0.470 & -0.237 & -0.020 & 0.024 \\
\hline Linear & -0.088 & -0.286 & -0.167 & -0.025 & 0.010 \\
\hline Log-Linear & -0.215 & -0.715 & -0.472 & -0.022 & 0.127 \\
\hline Almost Ideal & -0.146 & -0.541 & -0.332 & -0.016 & 0.080 \\
\hline \multicolumn{6}{|c|}{$\begin{array}{l}\text { Merger Price Effects - Quadratic Cost } \\
\text { Structure }\end{array}$} \\
\hline Logit & 0.012 & 0.000 & 0.004 & 0.024 & 0.035 \\
\hline Linear & 0.008 & 0.000 & 0.002 & 0.017 & 0.025 \\
\hline Log-Linear & 0.034 & 0.001 & 0.010 & 0.071 & 0.136 \\
\hline Almost Ideal & 0.022 & 0.000 & 0.006 & 0.045 & 0.087 \\
\hline
\end{tabular}


TABLE 4: PRICE INCREASE AND HHI CATEGORIES (FOUR FIRMS)

\section{Four Firms}

\begin{tabular}{|c|c|c|c|c|}
\hline \multicolumn{5}{|c|}{ Generalized Leontief Cost Structure } \\
\hline \multicolumn{5}{|c|}{ Threshold 1: Frequency of 5\% Price Increase } \\
\hline & Logit & Linear & Log-Linear & Almost Ideal \\
\hline Category (i) & 0.308 & 0.299 & 0.580 & 0.536 \\
\hline Category (i), (ii) or (iii) & 0.233 & 0.207 & 0.547 & 0.510 \\
\hline \multicolumn{5}{|c|}{ Threshold 2: Frequency of 10\% Price Increase } \\
\hline & Logit & Linear & Log-Linear & Almost Ideal \\
\hline Category (i) & 0.166 & 0.178 & 0.543 & 0.490 \\
\hline Category (i), (ii) or (iii) & 0.122 & 0.115 & 0.512 & 0.467 \\
\hline
\end{tabular}

Threshold 1: Frequency of 5\% Price Increase

\begin{tabular}{lrrrr} 
& Logit & Linear & Log-Linear & Almost Ideal \\
\cline { 2 - 5 } Category (i) & 0.626 & 0.611 & 0.901 & 0.835 \\
Category (i), (ii) or (iii) & 0.467 & 0.406 & 0.821 & 0.719
\end{tabular}

Threshold 2: Frequency of 10\% Price Increase

\begin{tabular}{lrrrr} 
& Logit & Linear & Log-Linear & Almost \\
\cline { 2 - 5 } Category (i) & 0.210 & 0.220 & 0.799 & 0.664 \\
Category (i), (ii) or (iii) & 0.137 & 0.135 & 0.673 & 0.523 \\
\hline
\end{tabular}


TABLE 5: PRICE INCREASE AND HHI CATEGORIES (SIX FIRMS)

Six Firms

\begin{tabular}{|c|c|c|c|c|}
\hline \multicolumn{5}{|c|}{ Generalized Leontief Cost Structure } \\
\hline \multicolumn{5}{|c|}{ Threshold 1: Frequency of 5\% Price Increase } \\
\hline & Logit & Linear & Log-Linear & Almost Ideal \\
\hline Category (i) & 0.226 & 0.219 & 0.565 & 0.510 \\
\hline Category (i), (ii) or (iii) & 0.117 & 0.088 & 0.459 & 0.432 \\
\hline \multicolumn{5}{|c|}{ Threshold 2: Frequency of 10\% Price Increase } \\
\hline & Logit & Linear & Log-Linear & Almost Ideal \\
\hline Category (i) & 0.107 & 0.100 & 0.532 & 0.448 \\
\hline Category (i), (ii) or (iii) & 0.045 & 0.025 & 0.429 & 0.391 \\
\hline \multicolumn{5}{|c|}{ Quadratic Cost Structure } \\
\hline \multicolumn{5}{|c|}{ Threshold 1: Frequency of 5\% Price Increase } \\
\hline & Logit & Linear & Log-Linear & Almost Ideal \\
\hline Category (i) & 0.530 & 0.478 & 0.925 & 0.871 \\
\hline Category (i), (ii) or (iii) & 0.160 & 0.099 & 0.721 & 0.544 \\
\hline \multicolumn{5}{|c|}{ Threshold 2: Frequency of 10\% Price Increase } \\
\hline & Logit & Linear & Log-Linear & Almost Ideal \\
\hline Category (i) & 0.075 & 0.077 & 0.861 & 0.664 \\
\hline Category (i), (ii) or (iii) & 0.014 & 0.014 & 0.478 & 0.313 \\
\hline
\end{tabular}


TABLE 6: PRICE INCREASE AND HHI CATEGORIES (EIGHT FIRMS)

Eight Firms

\section{Generalized Leontief Cost Structure}

Threshold 1: Frequency of 5\% Price Increase

\begin{tabular}{lrrrr} 
& Logit & Linear & Log-Linear & \multicolumn{2}{c}{ Almost Ideal } \\
\cline { 2 - 5 } Category (i) & 0.229 & 0.229 & 0.543 & 0.429 \\
Category (i), (ii) or (iii) & 0.084 & 0.056 & 0.418 & 0.391
\end{tabular}

Threshold 2: Frequency of 10\% Price Increase

\begin{tabular}{lrrrr} 
& Logit & Linear & Log-Linear & Almost Ideal \\
\cline { 2 - 6 } Category (i) & 0.057 & 0.057 & 0.486 & 0.371 \\
Category (i), (ii) or (iii) & 0.020 & 0.006 & 0.390 & 0.357 \\
\hline \multicolumn{5}{c}{ Quadratic Cost Structure } \\
\hline Threshold 1: Frequency of 5\% Price Increase & & \\
& Logit & Linear & Log-Linear & Almost Ideal \\
\cline { 2 - 6 } Category (i) & 0.543 & 0.543 & 0.971 & 0.943 \\
Category (i), (ii) or (iii) & 0.048 & 0.023 & 0.678 & 0.439 \\
Threshold 2: Frequency of 10\% Price Increase & & Almost Ideal \\
\hline & Logit & Linear & Log-Linear & 0.629 \\
\cline { 2 - 6 } Category (i) & 0.029 & 0.057 & 0.914 & 0.177 \\
Category (i), (ii) or (iii) & 0.001 & 0.002 & 0.339 & \\
\hline
\end{tabular}


TABLE 7: MERGER SCREENING ERRORS (FOUR, SIX, AND EIGHT FIRMS)

FOUR FIRMS

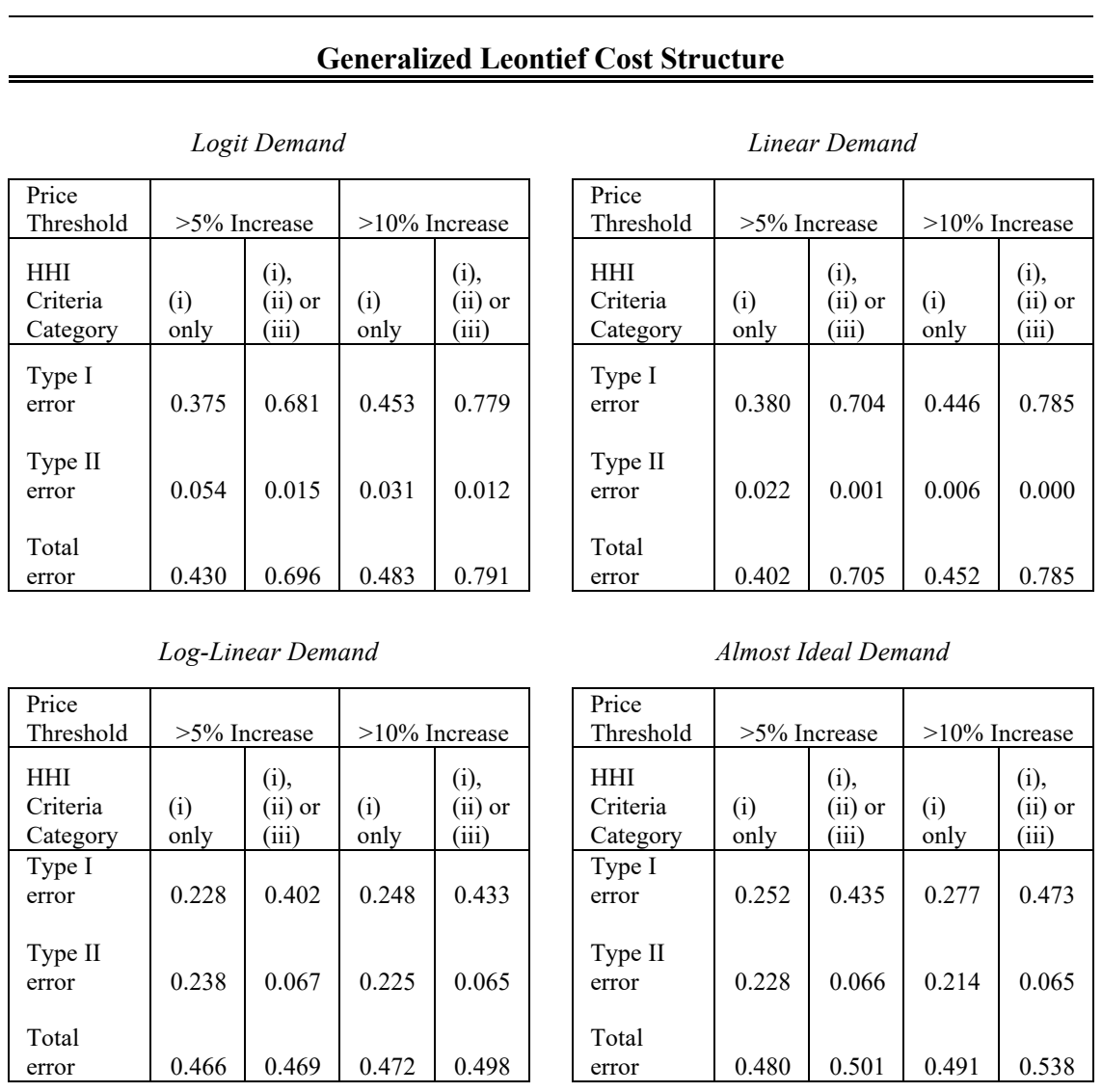




\begin{tabular}{|c|c|c|c|c|}
\hline \multicolumn{5}{|c|}{ Quadratic Cost St } \\
\hline \multicolumn{5}{|c|}{ Logit Demand } \\
\hline $\begin{array}{l}\text { Price } \\
\text { Threshold }\end{array}$ & $>5 \%$ & crease & & \\
\hline $\begin{array}{l}\text { HHI } \\
\text { Criteria } \\
\text { Category }\end{array}$ & $\begin{array}{l}\text { (i) } \\
\text { only }\end{array}$ & $\begin{array}{l}\text { (i), } \\
\text { (ii) } \\
\text { or } \\
\text { (iii) } \\
\end{array}$ & $\begin{array}{l}\text { (i) } \\
\text { only }\end{array}$ & $\begin{array}{l}\text { (i), } \\
\text { (ii) } \\
\text { or } \\
\text { (iii) } \\
\end{array}$ \\
\hline $\begin{array}{l}\text { Type I } \\
\text { error }\end{array}$ & 0.203 & 0.473 & 0.429 & 0.766 \\
\hline $\begin{array}{l}\text { Type II } \\
\text { error }\end{array}$ & 0.089 & 0.014 & 0.010 & 0.003 \\
\hline $\begin{array}{l}\text { Total } \\
\text { error }\end{array}$ & 0.292 & 0.487 & 0.439 & 0.769 \\
\hline
\end{tabular}

\begin{tabular}{|l|l|l|l|l|}
\hline \multicolumn{1}{|c|}{ Linear Demand } \\
\hline $\begin{array}{l}\text { Price } \\
\text { Threshold }\end{array}$ & $>5 \%$ Increase & \multicolumn{2}{|c|}{$>10 \%$ Increase } \\
\hline $\begin{array}{l}\text { HHI } \\
\text { Criteria } \\
\text { Category }\end{array}$ & $\begin{array}{l}\text { (i) } \\
\text { only }\end{array}$ & $\begin{array}{l}\text { (i) } \\
\text { or } \\
\text { (iii) }\end{array}$ & $\begin{array}{l}\text { (i) } \\
\text { only }\end{array}$ & $\begin{array}{l}\text { (i), (ii) } \\
\text { or (iii) }\end{array}$ \\
\hline $\begin{array}{l}\text { Type I } \\
\text { error }\end{array}$ & 0.211 & 0.527 & 0.423 & 0.767 \\
$\begin{array}{l}\text { Type II } \\
\text { error }\end{array}$ & 0.032 & 0.003 & 0.001 & 0.000 \\
$\begin{array}{l}\text { Total } \\
\text { error }\end{array}$ & 0.244 & 0.530 & 0.425 & 0.768 \\
\hline
\end{tabular}

\begin{tabular}{|l|l|l|l|l|}
\multicolumn{5}{|c|}{ Log-Linear Demand } \\
\begin{tabular}{|l|l|l|l|}
\hline $\begin{array}{l}\text { Price } \\
\text { Threshold }\end{array}$ & \multicolumn{2}{|c|}{$>5 \%$ Increase } & \multicolumn{2}{|c|}{$>10 \%$} \\
Increase
\end{tabular} \\
\hline $\begin{array}{l}\text { HHI } \\
\text { Criteria } \\
\text { Category }\end{array}$ & $\begin{array}{l}\text { (i) } \\
\text { only }\end{array}$ & $\begin{array}{l}\text { (ii) } \\
\text { or } \\
\text { (iii) }\end{array}$ & $\begin{array}{l}\text { (i) } \\
\text { (i) } \\
\text { only }\end{array}$ & $\begin{array}{l}\text { (ii) } \\
\text { or } \\
\text { (iii) }\end{array}$ \\
\hline $\begin{array}{l}\text { Type I } \\
\text { error }\end{array}$ & 0.054 & 0.159 & 0.109 & 0.291 \\
$\begin{array}{l}\text { Type II } \\
\text { error }\end{array}$ & 0.273 & 0.033 & 0.183 & 0.020 \\
$\begin{array}{l}\text { Total } \\
\text { error }\end{array}$ & 0.327 & 0.192 & 0.292 & 0.310 \\
\hline
\end{tabular}

\begin{tabular}{|c|c|c|c|c|}
\hline $\begin{array}{l}\text { Price } \\
\text { Threshold }\end{array}$ & $>5 \%$ & crease & $>10^{\circ}$ & Increase \\
\hline $\begin{array}{l}\text { HHI } \\
\text { Criteria } \\
\text { Category }\end{array}$ & $\begin{array}{l}\text { (i) } \\
\text { only }\end{array}$ & $\begin{array}{l}\text { (i), } \\
\text { (ii) } \\
\text { or } \\
\text { (iii) }\end{array}$ & $\begin{array}{l}\text { (i) } \\
\text { only }\end{array}$ & $\begin{array}{l}\text { (i), (ii) } \\
\text { or (iii) } \\
\end{array}$ \\
\hline $\begin{array}{l}\text { Type I } \\
\text { error }\end{array}$ & 0.090 & 0.250 & 0.183 & 0.423 \\
\hline $\begin{array}{l}\text { Type II } \\
\text { error }\end{array}$ & 0.207 & 0.023 & 0.116 & 0.012 \\
\hline $\begin{array}{l}\text { Total } \\
\text { error }\end{array}$ & 0.297 & 0.272 & 0.298 & 0.436 \\
\hline
\end{tabular}




\section{SIX FIRMS}

\begin{tabular}{|c|c|c|c|c|c|c|c|c|c|}
\hline \multicolumn{10}{|c|}{ Generalized Leontief Cost Structure } \\
\hline \multicolumn{5}{|c|}{ Logit Demand } & \multicolumn{5}{|c|}{ Linear Demand } \\
\hline $\begin{array}{l}\text { Price } \\
\text { Threshold }\end{array}$ & \multicolumn{2}{|c|}{$\begin{array}{c}>5 \% \\
\text { Increase }\end{array}$} & \multicolumn{2}{|c|}{$\begin{array}{c}>10 \% \\
\text { Increase }\end{array}$} & $\begin{array}{l}\text { Price } \\
\text { Threshold }\end{array}$ & \multicolumn{2}{|c|}{$>5 \%$ Increase } & \multicolumn{2}{|c|}{$>10 \%$ Increase } \\
\hline $\begin{array}{l}\text { HHI } \\
\text { Criteria } \\
\text { Category }\end{array}$ & $\begin{array}{l}\text { (i) } \\
\text { onl } \\
\mathrm{y}\end{array}$ & $\begin{array}{l}\text { (i), } \\
\text { (ii) } \\
\text { or } \\
\text { (iii) }\end{array}$ & $\begin{array}{l}\text { (i) } \\
\text { only }\end{array}$ & $\begin{array}{l}\text { (i), } \\
\text { (ii) } \\
\text { or } \\
\text { (iii) }\end{array}$ & $\begin{array}{l}\text { HHI } \\
\text { Criteria } \\
\text { Category }\end{array}$ & $\begin{array}{l}\text { (i) } \\
\text { only }\end{array}$ & $\begin{array}{l}\text { (i), } \\
\text { (ii) or } \\
\text { (iii) }\end{array}$ & $\begin{array}{l}\text { (i) } \\
\text { only }\end{array}$ & $\begin{array}{l}\text { (i), (ii) } \\
\text { or (iii) }\end{array}$ \\
\hline $\begin{array}{l}\text { Type I } \\
\text { error }\end{array}$ & 0.106 & 0.650 & 0.122 & 0.703 & $\begin{array}{l}\text { Type I } \\
\text { error }\end{array}$ & 0.107 & 0.672 & 0.123 & 0.717 \\
\hline $\begin{array}{l}\text { Type II } \\
\text { error }\end{array}$ & 0.077 & 0.022 & 0.033 & 0.014 & $\begin{array}{l}\text { Type II } \\
\text { error }\end{array}$ & 0.035 & 0.001 & 0.005 & 0.000 \\
\hline Total error & 0.183 & 0.672 & 0.155 & 0.717 & Total error & 0.143 & 0.673 & 0.129 & 0.717 \\
\hline \multicolumn{5}{|c|}{ Log-Linear Demand } & \multicolumn{5}{|c|}{ Almost Ideal Demand } \\
\hline $\begin{array}{l}\text { Price } \\
\text { Threshold }\end{array}$ & \multicolumn{2}{|c|}{$\begin{array}{c}>5 \% \\
\text { Increase }\end{array}$} & \multicolumn{2}{|c|}{$\begin{array}{c}>10 \% \\
\text { Increase }\end{array}$} & $\begin{array}{l}\text { Price } \\
\text { Threshold }\end{array}$ & \multicolumn{2}{|c|}{$>5 \%$ Increase } & \multicolumn{2}{|c|}{$>10 \%$ Increase } \\
\hline $\begin{array}{l}\text { HHI } \\
\text { Criteria } \\
\text { Category }\end{array}$ & $\begin{array}{l}\text { (i) } \\
\text { onl } \\
\mathrm{y}\end{array}$ & $\begin{array}{l}\text { (i), } \\
\text { (ii) } \\
\text { or } \\
\text { (iii) }\end{array}$ & $\begin{array}{l}\text { (i) } \\
\text { only }\end{array}$ & $\begin{array}{l}\text { (i), } \\
\text { (ii) } \\
\text { or } \\
\text { (iii) }\end{array}$ & $\begin{array}{l}\text { HHI } \\
\text { Criteria } \\
\text { Category }\end{array}$ & $\begin{array}{l}\text { (i) } \\
\text { only }\end{array}$ & $\begin{array}{l}\text { (i), } \\
\text { (ii) or } \\
\text { (iii) } \\
\end{array}$ & $\begin{array}{l}\text { (i) } \\
\text { only }\end{array}$ & $\begin{array}{l}\text { (i), (ii) } \\
\text { or (iii) }\end{array}$ \\
\hline $\begin{array}{l}\text { Type I } \\
\text { error }\end{array}$ & 0.060 & 0.398 & 0.064 & 0.420 & $\begin{array}{l}\text { Type I } \\
\text { error }\end{array}$ & 0.067 & 0.418 & 0.076 & 0.448 \\
\hline $\begin{array}{l}\text { Type II } \\
\text { error }\end{array}$ & 0.401 & 0.140 & 0.381 & 0.138 & $\begin{array}{l}\text { Type II } \\
\text { error }\end{array}$ & 0.386 & 0.138 & 0.361 & 0.135 \\
\hline Total error & 0.460 & 0.538 & 0.445 & 0.558 & Total error & 0.453 & 0.556 & 0.437 & 0.583 \\
\hline
\end{tabular}




\begin{tabular}{l}
\hline Quadratic Cost Structure (Six Firms) \\
\hline \hline
\end{tabular}

\begin{tabular}{|c|c|c|c|c|}
\hline \multicolumn{5}{|c|}{ Logit Demand } \\
\hline $\begin{array}{l}\text { Price } \\
\text { Threshold }\end{array}$ & \multicolumn{2}{|c|}{$>5 \%$ Increase } & \multicolumn{2}{|c|}{$>10 \%$ Increase } \\
\hline $\begin{array}{l}\text { HHI } \\
\text { Criteria } \\
\text { Category }\end{array}$ & $\begin{array}{l}\text { (i) } \\
\text { only }\end{array}$ & $\begin{array}{l}\text { (i), } \\
\text { (ii) or } \\
\text { (iii) }\end{array}$ & $\begin{array}{l}\text { (i) } \\
\text { only }\end{array}$ & $\begin{array}{l}\text { (i), } \\
\text { (ii) or } \\
\text { (iii) }\end{array}$ \\
\hline $\begin{array}{l}\text { Type I } \\
\text { error }\end{array}$ & 0.064 & 0.618 & 0.127 & 0.726 \\
\hline $\begin{array}{l}\text { Type II } \\
\text { error } \\
\text { Total }\end{array}$ & 0.055 & 0.010 & 0.000 & 0.000 \\
\hline error & 0.119 & 0.628 & 0.127 & 0.726 \\
\hline
\end{tabular}

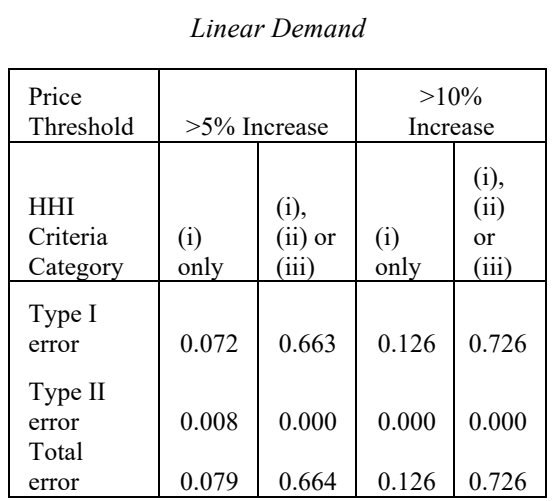

Log-Linear Demand
\begin{tabular}{|l|l|l|l|l|}
\hline $\begin{array}{l}\text { Price } \\
\text { Threshold }\end{array}$ & \multicolumn{2}{|c|}{$>5 \%$ Increase } & \multicolumn{2}{|c|}{$>10 \%$ Increase } \\
\hline $\begin{array}{l}\text { HHI } \\
\text { Criteria } \\
\text { Category }\end{array}$ & $\begin{array}{l}\text { (i) } \\
\text { only }\end{array}$ & $\begin{array}{l}\text { (i), } \\
\text { (ii) or } \\
\text { (iii) }\end{array}$ & $\begin{array}{l}\text { (i) } \\
\text { only }\end{array}$ & $\begin{array}{l}\text { (i), } \\
\text { (ii) or } \\
\text { (iii) }\end{array}$ \\
\hline $\begin{array}{l}\text { Type I } \\
\text { error }\end{array}$ & 0.010 & 0.206 & 0.019 & 0.384 \\
$\begin{array}{l}\text { Type II } \\
\text { error }\end{array}$ & 0.457 & 0.053 & 0.250 & 0.015 \\
$\begin{array}{l}\text { Total } \\
\text { error }\end{array}$ & 0.467 & 0.258 & 0.269 & 0.399 \\
\hline
\end{tabular}

\begin{tabular}{|c|c|c|c|c|}
\hline $\begin{array}{l}\text { Price } \\
\text { Threshold }\end{array}$ & $>5 \% \mathrm{I}$ & crease & & \\
\hline $\begin{array}{l}\text { HHI } \\
\text { Criteria } \\
\text { Category }\end{array}$ & $\begin{array}{l}\text { (i) } \\
\text { only }\end{array}$ & $\begin{array}{l}\text { (i), } \\
\text { (ii) or } \\
\text { (iii) }\end{array}$ & $\begin{array}{l}\text { (i) } \\
\text { only }\end{array}$ & $\begin{array}{l}\text { (i), } \\
\text { (ii) } \\
\text { or } \\
\text { (iii) }\end{array}$ \\
\hline $\begin{array}{l}\text { Type I } \\
\text { error }\end{array}$ & 0.018 & 0.336 & 0.046 & 0.506 \\
\hline $\begin{array}{l}\text { Type II } \\
\text { error }\end{array}$ & 0.304 & 0.024 & 0.146 & 0.007 \\
\hline $\begin{array}{l}\text { Total } \\
\text { error }\end{array}$ & 0.322 & 0.359 & 0.192 & 0.512 \\
\hline
\end{tabular}




\section{EIGHT FIRMS}

\begin{tabular}{|c|c|c|c|c|c|c|c|c|c|}
\hline \multicolumn{10}{|c|}{ Generalized Leontief Cost Structure } \\
\hline \multicolumn{5}{|c|}{ Logit Demand } & \multicolumn{5}{|c|}{ Linear Demand } \\
\hline $\begin{array}{l}\text { Price } \\
\text { Threshold }\end{array}$ & \multicolumn{2}{|c|}{$>5 \%$ Increase } & \multicolumn{2}{|c|}{$\begin{array}{c}>10 \% \\
\text { Increase }\end{array}$} & $\begin{array}{l}\text { Price } \\
\text { Threshold }\end{array}$ & \multicolumn{2}{|c|}{$>5 \%$ Increase } & \multicolumn{2}{|c|}{$\begin{array}{c}>10 \% \\
\text { Increase }\end{array}$} \\
\hline $\begin{array}{l}\text { HHI } \\
\text { Criteria } \\
\text { Category }\end{array}$ & $\begin{array}{l}\text { (i) } \\
\text { only }\end{array}$ & $\begin{array}{l}\text { (i), } \\
\text { (ii) or } \\
\text { (iii) } \\
\end{array}$ & $\begin{array}{l}\text { (i) } \\
\text { only }\end{array}$ & $\begin{array}{l}\text { (i), } \\
\text { (ii) or } \\
\text { (iii) } \\
\end{array}$ & $\begin{array}{l}\text { HHI } \\
\text { Criteria } \\
\text { Category }\end{array}$ & $\begin{array}{l}\text { (i) } \\
\text { only }\end{array}$ & $\begin{array}{l}\text { (i), } \\
\text { (ii) or } \\
\text { (iii) }\end{array}$ & $\begin{array}{l}\text { (i) } \\
\text { only }\end{array}$ & $\begin{array}{l}\text { (i), } \\
\text { (ii) or } \\
\text { (iii) } \\
\end{array}$ \\
\hline $\begin{array}{l}\text { Type I } \\
\text { error }\end{array}$ & 0.009 & 0.382 & 0.011 & 0.409 & $\begin{array}{l}\text { Type I } \\
\text { error }\end{array}$ & 0.009 & 0.394 & 0.011 & 0.415 \\
\hline $\begin{array}{l}\text { Type II } \\
\text { error }\end{array}$ & 0.058 & 0.026 & 0.023 & 0.016 & $\begin{array}{l}\text { Type II } \\
\text { error }\end{array}$ & 0.024 & 0.003 & 0.002 & 0.000 \\
\hline Total error & 0.067 & 0.408 & 0.035 & 0.425 & Total error & 0.033 & 0.397 & 0.013 & 0.415 \\
\hline \multicolumn{5}{|c|}{ Log-Linear Demand } & \multicolumn{5}{|c|}{ Almost Ideal Demand } \\
\hline $\begin{array}{l}\text { Price } \\
\text { Threshold }\end{array}$ & \multicolumn{2}{|c|}{$>5 \%$ Increase } & \multicolumn{2}{|c|}{$\begin{array}{c}>10 \% \\
\text { Increase }\end{array}$} & $\begin{array}{l}\text { Price } \\
\text { Threshold }\end{array}$ & \multicolumn{2}{|c|}{$>5 \%$ Increase } & \multicolumn{2}{|c|}{$\begin{array}{c}>10 \% \\
\text { Increase }\end{array}$} \\
\hline $\begin{array}{l}\text { HHI } \\
\text { Criteria } \\
\text { Category }\end{array}$ & $\begin{array}{l}\text { (i) } \\
\text { only }\end{array}$ & $\begin{array}{l}\text { (i), } \\
\text { (ii) or } \\
\text { (iii) } \\
\end{array}$ & $\begin{array}{l}\text { (i) } \\
\text { only }\end{array}$ & $\begin{array}{l}\text { (i), } \\
\text { (ii) or } \\
\text { (iii) }\end{array}$ & $\begin{array}{l}\text { HHI } \\
\text { Criteria } \\
\text { Category }\end{array}$ & $\begin{array}{l}\text { (i) } \\
\text { only }\end{array}$ & $\begin{array}{l}\text { (i), } \\
\text { (ii) or } \\
\text { (iii) } \\
\end{array}$ & $\begin{array}{l}\text { (i) } \\
\text { only }\end{array}$ & $\begin{array}{l}\text { (i), } \\
\text { (ii) or } \\
\text { (iii) } \\
\end{array}$ \\
\hline $\begin{array}{l}\text { Type I } \\
\text { error }\end{array}$ & 0.005 & 0.243 & 0.006 & 0.255 & $\begin{array}{l}\text { Type I } \\
\text { error }\end{array}$ & 0.007 & 0.254 & 0.007 & 0.268 \\
\hline $\begin{array}{l}\text { Type II } \\
\text { error }\end{array}$ & 0.435 & 0.267 & 0.417 & 0.260 & $\begin{array}{l}\text { Type II } \\
\text { error }\end{array}$ & 0.421 & 0.263 & 0.399 & 0.254 \\
\hline Total error & 0.441 & 0.510 & 0.423 & 0.514 & Total error & 0.428 & 0.517 & 0.406 & 0.522 \\
\hline
\end{tabular}




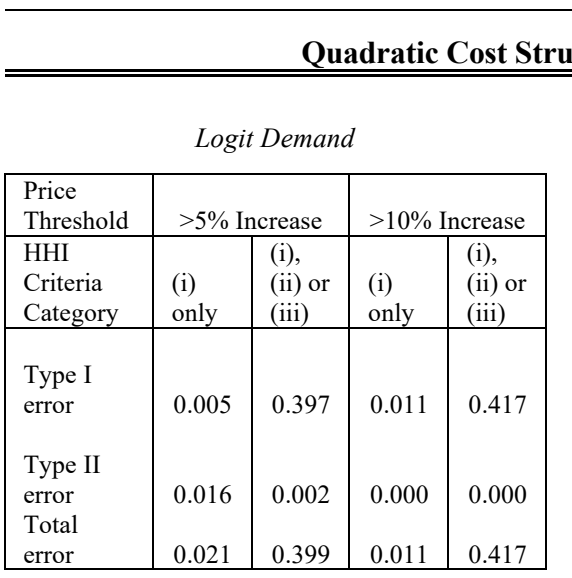

Log-Linear Demand

\begin{tabular}{|l|l|l|l|l|}
\hline $\begin{array}{l}\text { Price } \\
\text { Threshold }\end{array}$ & \multicolumn{2}{|c|}{$>5 \%$ Increase } & \multicolumn{2}{|c|}{$>10 \%$ Increase } \\
\hline $\begin{array}{l}\text { HHI } \\
\begin{array}{l}\text { Criteria } \\
\text { Category }\end{array}\end{array}$ & $\begin{array}{l}\text { (i) } \\
\text { only }\end{array}$ & $\begin{array}{l}\text { (i) } \\
\text { (ii) or } \\
\text { (iii) }\end{array}$ & $\begin{array}{l}\text { (i) } \\
\text { only }\end{array}$ & $\begin{array}{l}\text { (ii) or } \\
\text { (iii) }\end{array}$ \\
\hline $\begin{array}{l}\text { Type I } \\
\text { error }\end{array}$ & 0.000 & 0.134 & 0.001 & 0.276 \\
$\begin{array}{l}\text { Type II } \\
\text { error } \\
\text { Total } \\
\text { error }\end{array}$ & 0.378 & 0.107 & 0.151 & 0.020 \\
\hline
\end{tabular}

Linear Demand

\begin{tabular}{|l|l|l|l|l|}
\hline $\begin{array}{l}\text { Price } \\
\text { Threshold }\end{array}$ & \multicolumn{2}{|c|}{$>5 \%$ Increase } & \multicolumn{2}{|c|}{$>10 \%$ Increase } \\
\hline $\begin{array}{l}\text { HHI } \\
\text { Criteria } \\
\text { Category }\end{array}$ & $\begin{array}{l}\text { (i) } \\
\text { only }\end{array}$ & $\begin{array}{l}\text { (i) } \\
\text { (ii) or } \\
\text { (iii) }\end{array}$ & $\begin{array}{l}\text { (i) } \\
\text { only }\end{array}$ & $\begin{array}{l}\text { (i) } \\
\text { (ii) or } \\
\text { (iii) }\end{array}$ \\
\hline $\begin{array}{l}\text { Type I } \\
\text { error }\end{array}$ & 0.005 & 0.408 & 0.011 & 0.417 \\
$\begin{array}{l}\text { Type II } \\
\text { error } \\
\text { Total } \\
\text { error }\end{array}$ & 0.003 & 0.000 & 0.000 & 0.000 \\
\hline
\end{tabular}

Almost Ideal Demand

\begin{tabular}{|l|l|l|l|l|}
\hline $\begin{array}{l}\text { Price } \\
\text { Threshold }\end{array}$ & \multicolumn{2}{|c|}{$>5 \%$ Increase } & \multicolumn{2}{c|}{$>10 \%$ Increase } \\
\hline $\begin{array}{l}\text { HHI } \\
\begin{array}{l}\text { Criteria } \\
\text { Category }\end{array}\end{array}$ & $\begin{array}{l}\text { (i) } \\
\text { only }\end{array}$ & $\begin{array}{l}\text { (i) } \\
\text { (ii) or } \\
\text { (iii) }\end{array}$ & $\begin{array}{l}\text { (i) } \\
\text { only }\end{array}$ & $\begin{array}{l}\text { (i) } \\
\text { (ii) or } \\
\text { (iii) }\end{array}$ \\
\hline $\begin{array}{l}\text { Type I } \\
\text { error }\end{array}$ & 0.001 & 0.234 & 0.004 & 0.344 \\
$\begin{array}{l}\text { Type II } \\
\text { error } \\
\text { Total } \\
\text { error }\end{array}$ & 0.213 & 0.041 & 0.080 & 0.013 \\
\hline
\end{tabular}




\section{CONCLUSION}

One of the amazing things in the field of antitrust is that we are still figuring things out. This emblematic trajectory of the way in which efficiencies in merger review has evolved reveals that there is still a lot to be understood and developed on the way we conduct our policies. While the Rule of Reason and the need to determine net competition effects of mergers exists, efficiencies will be an underlying topic to many of the main topics of discussion, such as estimation of unilateral effects, welfare standards, and quantitative techniques. Kenneth Heyer, a senior economist at the Department of Justice Antitrust Division, goes so far as to state that efficiency, not competition, is the goal of antitrust. ${ }^{102}$

For a long time, merger analyses have relied on market concentration as a proxy and indicator of market power. Although simple economic models and existent literature show the benefits and monotonic relationship between concentration and the ability to price above the competitive level, in the presence of merger efficiencies, the HHI and purely concentration-based measures may not be able to fully capture the full effect. As a matter of fact, the higher the potential efficiency gains involved in a proposed merger, the less reliable a naïve measure of increased concentration will be in indicating likelihood of harm to consumers. Clearly, there is a need to move to more structural-based models and unilateral effect estimates, as those may offer better merger screening, as shown in the literature.

The future of merger efficiencies in antitrust analysis depends on many premises. Whether antitrust law should be concerned and to which extent with allocative effects of welfare, and whether consumer welfare standard will continue to be the primary view. Furthermore, all discourse on accounting efficiencies as an antitrust defense depends on our ability to advance prediction methods ex ante, to provide quantitative reliable estimates of efficiencies, and to increase our confidence in the likelihood of these efficiencies to be realized.

102. William J. Kolasky, Deputy Assistant Att'y Gen., Antitrust Div., U.S. Dep't of Justice, United States and European Competition Policy: Are There More Differences Than We Care to Admit?, Address Before the European Policy Center (Apr. 10, 2002), https://www.justice.gov/atr/speech /united-states-and-european-competition-policy-are-there-more-differences-we-care-admit [https:// perma.cc/6MZA-RLK7] ("For us, as Ken Heyer stated very nicely yesterday, 'efficiencies are the goal; competition is the process."); see also Summers, supra note 28, at 358 ("[I]t needs to be remembered that the goal is efficiency, not competition. The ultimate goal is that there be efficiency."). 